Article

\title{
Climate Change-Induced Shift of Tree Growth Sensitivity at a Central Himalayan Treeline Ecotone
}

\author{
Niels Schwab ${ }^{1, *}$ (D), Ryszard J. Kaczka ${ }^{2}$ (D), Karolina Janecka ${ }^{3}$, Jürgen Böhner ${ }^{1}$, \\ Ram P. Chaudhary ${ }^{4}$, Thomas Scholten ${ }^{5}$ and Udo Schickhoff ${ }^{1}$ \\ 1 Physical Geography, Center for Earth System Research and Sustainability (CEN), University of Hamburg, \\ 20146 Hamburg, Germany; juergen.boehner@uni-hamburg.de (J.B.); udo.schickhoff@uni-hamburg.de (U.S.) \\ 2 Faculty of Earth Sciences, University of Silesia in Katowice, 41-200 Sosnowiec, Poland; \\ ryszard.kaczka@us.edu.pl \\ 3 Institute of Botany and Landscape Ecology, University of Greifswald, 17489 Greifswald, Germany; \\ karolinaejanecka@gmail.com \\ 4 Research Centre for Applied Science and Technology (ReCAST), Tribhuvan University, Kirtipur 44618, \\ Nepal; ram@cdbtu.wlink.com.np \\ 5 Department of Geosciences, Chair of Soil Science and Geomorphology, University of Tübingen, \\ 72070 Tübingen, Germany; thomas.scholten@uni-tuebingen.de \\ * Correspondence: niels.schwab@uni-hamburg.de; Tel.: +49-40-42838-5929
}

Received: 4 April 2018; Accepted: 10 May 2018; Published: 13 May 2018

\begin{abstract}
Himalayan treelines are exposed to above average climate change impact, resulting in complex tree growth-climate relationships for Himalayan Silver Fir (Abies spectabilis (D. Don) Spach) at central Himalayan treelines. The majority of recent studies detected current tree growth sensitivity to dry conditions during pre-monsoon seasons. The aim of this study was to analyze growth-climate relationships for more than a century for a treeline ecotone in east-central Nepal and to test for Blue Intensity (BI; used as a surrogate of maximum late wood density) as climate proxy. We determined the relationships of Abies spectabilis radial tree growth and BI to climate by correlating both to temperature, precipitation and drought index data. The results showed a significantly unstable dendroclimatic signal over time. Climate warming-induced moisture deficits during pre-monsoon seasons became a major factor limiting radial tree growth during recent decades. Earlier in time, the dendroclimatic signal was weaker, predominantly reflecting a positive relationship of tree growth and summer temperature. Compared to radial tree growth, BI showed a different but strong climate signal. Temporally unstable correlations may be attributed to increasing effects of above-average rates of climate warming. An extended network of Himalayan tree-ring sites is needed to further analyze cause-effect relationships and to solve this attribution problem.
\end{abstract}

Keywords: Blue Intensity; climate warming; Himalayan Silver Fir (Abies spectabilis), Nepal Himalaya; temporal dynamics; tree growth-climate correlation; treeline ecotone; tree-ring width

\section{Introduction}

Mountains of the world, including the Himalaya, belong to the regions most affected by climate change. Warming trends of the annual mean surface air temperature of up to $1.5^{\circ} \mathrm{C}$ were detected over the Tibetan Plateau and the Himalaya during the period 1991-2012 [1-3]. Above-average warming rates trigger multiple vegetation responses such as changes in phenology, productivity, species composition of communities, structure, and elevational ranges of species [4-7]. In this regard, elevational shifts of alpine treelines and tree growth-climate relationships have received much attention (e.g., [8-12]). However, the knowledge concerning tree growth sensitivity and response to climate change is 
still rather limited [13-15]. Growth-climate relationships are influenced, inter alia, by length and temperature of the growing season [16-18]. Other influencing factors include moisture availability, nitrogen deposition, winter snowpack, snow melt and frost intensity [14-16,19]. Tree growth and various climate variables do not show consistent relations. In the Himalaya, climate-growth relations vary across different regions even for the same species [20-22]. Thus, more tree-ring based studies on different treeline tree species, tree-ring proxies and various mountain regions are needed to close this knowledge gap.

Various treeline tree species have been analyzed for tree growth-climate relationships in the Himalayan subregions (e.g., [23-27]). One of the frequently studied species is the widely distributed Himalayan Silver Fir, Abies spectabilis (D. Don) Spach. Some Abies spectabilis studies found a positive correlation of radial tree growth and the temperature of the current and previous growing season (e.g., $[28,29])$. Others pointed to a limitation of tree growth by winter temperature (e.g., [30,31]) or by available moisture in precipitation-deficient pre-monsoon seasons (e.g., $[11,32,33])$. With regard to generally sparse and partially inconsistent results, in some cases, even from study areas relatively near to each other (e.g., [10]), additional studies are needed, preferably from near natural sites.

Tree-ring width-climate relations are generally recognized to be stable over time [34-36]. However, climatic factors formerly limiting tree growth can alter and/or lose their limiting character while other factors become main drivers [37-39]. For instance, previously temperature-sensitive tree-ring widths showed less or no sensitivity to temperature in recent decades, sometimes even resulting in inverted tree growth-temperature relations [38,40-44]. Such inversions of the tree growth-climate relationships during an analyzed period are termed "divergence problem" [43] while "divergence phenomenon" $[43,45]$ and "divergence effect" $[43,46]$ are related to declines in temperature sensitivity. Divergence effects matter especially in the context of tree-ring based climate reconstruction [43,46,47]. A climate warming-induced increase in evapotranspiration and consequent moisture stress was often mentioned as the potential main cause for divergence effects $[43,48]$, possibly linked to temperature thresholds [49]. Other climate-related causes include direct limitation by precipitation [38], differential responses to maximum and minimum temperatures [43], and changes in seasonality, e.g., of winter precipitation and snowmelt [19]. Decreasing stratospheric ozone concentrations as well as global dimming caused by cloud cover changes and atmospheric contamination, both influencing photosynthesis efficiency and tree productivity, are further potentially relevant factors [43]. In summary, anthropogenic impacts are most likely causing the divergence phenomenon [43,50]. From a methodological point of view, divergence problems might result from "detrending end effects", caused by the detrending procedure of tree-ring series $[43,46]$. The majority of chronologies in which the divergence phenomenon was detected originated from high latitudes (e.g., [38,51,52]), however, there is also evidence from other regions, including high mountains $[46,53,54]$. Variations of environmental factors within the area of origin of a chronology might also cause diverging tree growth-climate interactions (e.g., [48,55]), often termed individualistic tree growth responses $[47,55,56]$ rather than divergence phenomena. As long as trees growing within the same stand are not genetically and physiologically identical, some degree of individual response to environmental factors can be expected in the frame of natural adaptation. The knowledge of divergence effects and the stability of explicitly moisture-related relationships is still deficient [57].

The majority of central Himalayan tree-ring studies investigated growth-climate relationships for rather short periods due to the lack of long instrumental records of climate data. Some recent studies used gridded climate data that cover longer time periods without referring to divergence of correlations or without finding unstable ones (e.g., [58]). Unstable correlations of Abies spectabilis tree growth with climate variables were recently mentioned by a couple of studies [28,59]. However, the number of studies that investigate temporal stability and potential divergence phenomena in the Himalaya is insufficient, pointing to a great need for further research.

Maximum latewood density (MXD), a function of latewood cell size and cell wall thickness [34], provides a strong climate signal, especially of growing season temperature in high latitudes and 
elevations $[60,61]$. The integration of wood density and its relation to climate can increase the precision of biomass and carbon sequestration estimations based on tree-ring width or $\mathrm{CO}_{2}$ fluxes measured by eddy covariance [62-64]. The only study on the relationship between climate and MXD of Abies spectabilis from Nepal [65] showed a significantly positive influence of pre-monsoon and monsoon temperatures and a negative impact of monsoon precipitation on minimum wood density, while mean and maximum densities correlated positively with late-monsoon and the entire growing season temperatures, respectively. Another study from the western Indian Himalaya showed a negative relationship of June temperature and Abies spectabilis MXD, pointing to late spring moisture sensitivity [59].

Blue Intensity (BI) has increasingly been applied in recent years as a reliable surrogate for MXD [66-70]. The BI parameter is measured as value of the blue light absorbed by wood surface recorded directly from the RGB (red, green, and blue light components) digital image [70,71]. The close relationship of MXD and BI might be attributed to the effective absorption of short wavelength energy by lignin and potentially co-varying structural wood components $[67,70]$. BI studies which could provide an additional climate proxy and improve carbon allocation estimates were not conducted in the Himalaya so far.

This paper analyzes long-term growth-climate relationships for a treeline ecotone in east-central Nepal, and the applicability of BI as a climate proxy. We hypothesize that the occasionally detected instability of Abies spectabilis tree growth-climate relationships over long timeframes is a general pattern which is also emergent in the Rolwaling treeline ecotone. We further hypothesize that BI as a wood density proxy should be less affected by climatic changes due to the previously assessed stability of wood density signals. To contribute to a better understanding of the dependence of tree growth on (changing) climate in the central Himalaya, this paper aims at: (i) analyzing the relationships of Abies spectabilis radial growth, measured by tree-ring width, to climate variables on the basis of more than one century-long gridded climate data; (ii) investigating the temporal stability of tree ring width (TRW)-climate relationships to check whether diverging growth trends occur in the course of distinctly changing climate conditions; and (iii) analyzing the relationships of Abies spectabilis BI (as a surrogate for MXD) and their temporal stability to the aforementioned climate data in order to compare the temporal stabilities of the BI and TRW signals.

\section{Materials and Methods}

\subsection{Study Area and Sampling Site}

We collected tree-ring samples at a north-facing slope in the Rolwaling valley, Gaurishankar Conservation Area, Dolakha District, East Central Nepal (Figure 1). The samples originate from the upper subalpine forest between ca. 3700 and $4000 \mathrm{~m}$ a.s.l., i.e., from the lower section of the treeline ecotone. The cored individuals grow in a mixed forest composed of Abies spectabilis and Betula utilis D. Don with Rhododendron campanulatum D. Don and Sorbus microphylla (Wallich ex J. D. Hooker) Wenzig as a second tree layer. Abies spectabilis and Betula utilis are co-dominant constituents in the lower part of the subalpine forest with an increasing percentage of Betula towards higher elevation. Above the sampling area, at the treeline, the subalpine forest gives way to a dense Rhododendron campanulatum krummholz belt which is replaced upslope by alpine vegetation dominated by Rhododendron dwarf thickets (cf. [72-74]). Soils in the treeline ecotone are classified as podzols [18]. Due to the valley's remote location, inaccessibility, low population density, and relevance for the Buddhist mythology [75], the entire treeline ecotone is in near-natural condition [72]. The study site's climate is classified as temperate with dry winter and warm summer (Köppen-Geiger Cwb) [76]. The seasons are usually defined as winter (December to February), pre-monsoon/spring (March to May), monsoon (June to September), and post-monsoon (October to November) [77]. Precipitation during monsoon season accounts for ca. $80 \%$ of the total annual precipitation. The pre-monsoon season is a dry period 
with high solar insolation, maximum temperatures, small amounts of precipitation and low available soil water capacity (cf. Figure 2) [18,78].
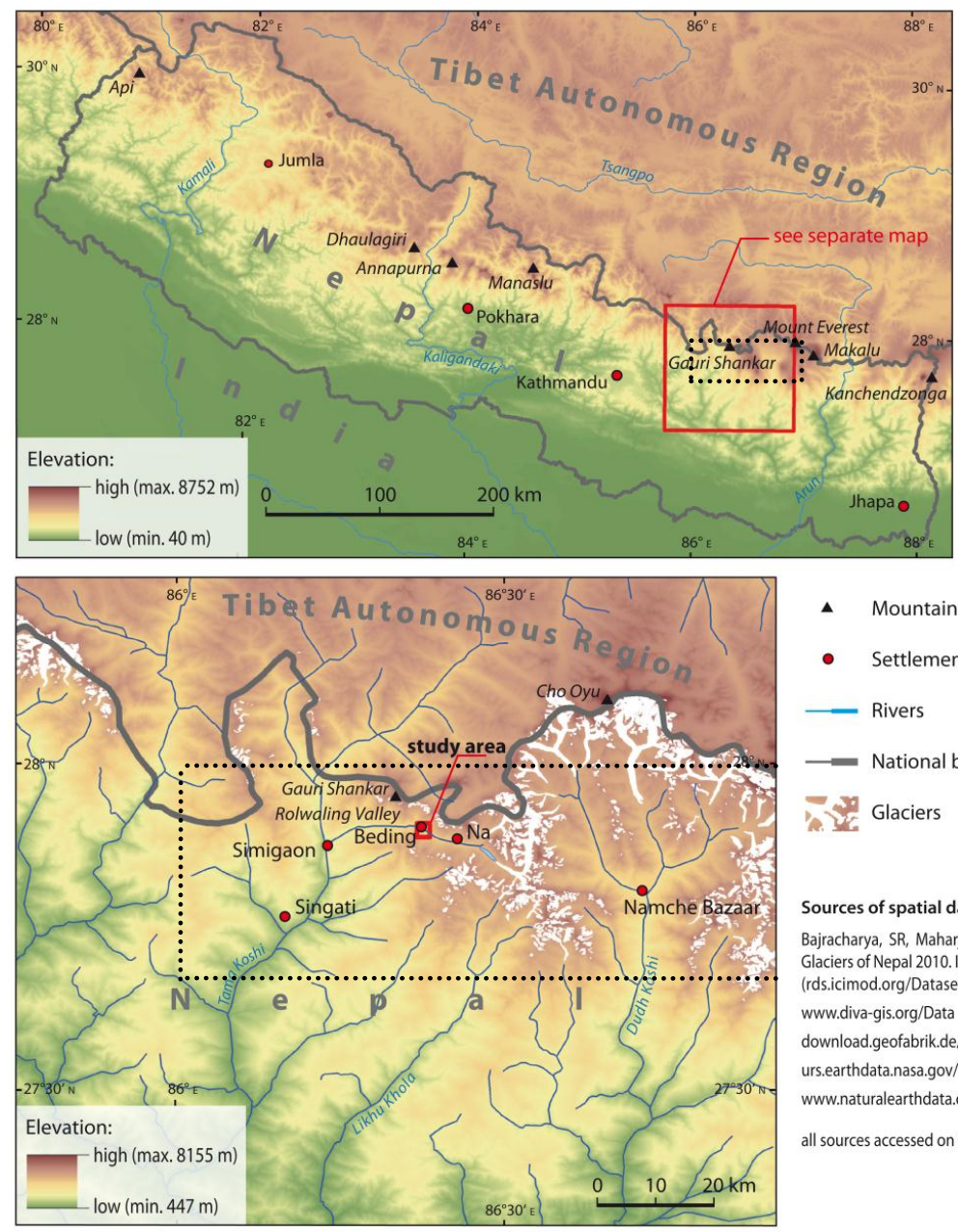

- Mountain peaks

- Settlements

— Rivers

- National border

1. Glaciers

Sources of spatial data:

Bajracharya, SR, Maharjan, SB, Shrestha, F (2015)

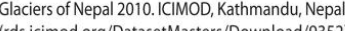
www.diva-gis.org/Data

download.geofabrik.de/asia/nepal.html

urs.earthdata.nasa.gov/

www.naturalearthdata.com

all sources accessed on 2016-03-09

Figure 1. Study area in east-central Nepal. The dashed rectangle shows the approximate position of University of East Anglia Climatic Research Unit (CRU) grid cells.



(a)



(b)

Figure 2. Climate charts of used CRU data. See Figure 1 for the location of the grid cells. The entire period of CRU data availability (a) shows higher amounts of precipitation in November and June and lower annual mean temperatures compared to last decades (b). Diagrams were produced with $\mathrm{R}$ package climatol [79]. 


\subsection{Tree-Ring Data}

The target species, Abies spectabilis, occurs as a common coniferous species in the central Himalayan arc between 3000 and $4200 \mathrm{~m}$ a.s.l. [80]. We applied standard sampling and core preparation methods [36,81]. We sampled all individuals growing within randomly selected $20 \times 20 \mathrm{~m}^{2}$ plots in homogenous stands at the upper subalpine forest which were established for intensive treeline ecological studies (e.g., [73]). For further details on site-ecological conditions, see [72-74,82]. In addition, we cored old trees around these plots to increase the pool of data for dendroecological and dendroclimatological analyses. We collected at least two cores per tree during two sampling campaigns in 2013 and 2014. In total, 359 radii of 114 trees were prepared and scanned in darkroom conditions at $2400 \mathrm{dpi}$, in RGB mode using an Epson Perfection V850 optical flatbed scanner. To measure BI, the scanner was calibrated according to the International Colour Consortium (ICC) standard with the use of a standard calibration target (IT 8.7/2) printed on Kodak Professional Endure paper and the SilverFast 8.0 scanning software (LaserSoft Imaging, Kiel, Germany). Both TRW and BI were measured in CooRecorder 8.1.1 software (Cybis Elektronik \& Data AB, Saltsjöbaden, Sweden). Samples with rot and compression wood were excluded from measuring since the occurrence of compression wood in tree ring biases the climatic signal $[83,84]$. The settings in CooRecorder were adjusted to measure only BI of the latewood, therefore one collector was applied. The fir wood was characterized by a clear pattern of annual ring boundaries and lack of resin ducts, therefore a rather wide area of BI probing was selected (the dimensions of the so-called "frame": 100/3/50 pixels, width/front/late wood overlap respectively with the relative margin between frames maximum $50 \%$ ); for details see $[71,85]$. All TRW and BI series were cross-dated visually in CDendro 8.1.1 (Cybis Elektronik \& Data AB, Saltsjöbaden, Sweden) and statistically in Cofecha 6.06P software (Laboratory of Tree-Ring Research, University of Arizona, Tucson, and Instituto Argentino de Nivologia y Glaciologia (IANIGLA), Mendoza, Argentina) [86].

We started building the TRW chronology with 359 radii of 114 trees initially. Due to poor quality (mold, decay, and distorted growth patterns due to compression wood and branches) and short length (distorting juvenile effects), cross-dating was not reliable for all series (low inter-series correlation). Thus, some series were not included in TRW and/or BI chronologies. In total, we included 81 radii of 51 trees and 87 radii of 52 trees in the final TRW and BI chronologies, respectively. However, the two chronologies do not represent exactly the same bunch of cores (but they originate from the collection of 359 radii), i.e., samples fitted partially only to TRW and/or only to BI chronologies. For instance, BI could not be measured on samples which were partly rotten or affected by compression wood due to significant changes of color, including reflectance of blue light. As a result of visual and statistical cross-dating we added five missing rings in single series of both chronologies $(1877,1887,1892,1906$ and 1963). The raw TRW and BI chronologies exhibited significance $(p<0.001)$ for the long term declining growth trends, interrupted by several breakpoints that were also visible for individual trees. Therefore, standardization was applied to remove the age trends in series of both proxies.

The standard TRW and BI chronologies were calculated by applying a 100-year cubic smoothing splines with fixed 50\% variance cutoff in the software ARSTAN 44h3 (Tree-Ring Laboratory, Lamont-Doherty Earth Observatory, Palisades, New York, USA) to remove age-related growth trends [87]. To assess unbiased temporal stability of the tree growth-climate relations, we applied a spline that preserves low frequency variability following [88]. To reduce heteroscedastic behavior of the tree-ring series, we applied a data-adaptive power transformation prior to the detrending process [89].

To assess chronology quality and properties, we calculated the following statistics for the entire chronology and for the analyzed period 1902-2012: mean sensitivity, mean inter-series correlation, running and mean $R$-bar, running and mean expressed population signal (EPS), signal-to-noise ratio, and first-order autocorrelation. Mean sensitivity shows the interannual variability of tree growth. Mean inter-series correlation is the average of all individual series' master chronology correlations coefficients and indicates the common stand-level signal. The signal strength throughout the chronology is represented by the running and the mean R-bar which represent correlations 
between all series in 30-year windows with 15-year overlap. EPS was calculated for the same periods revealing the common variability in a chronology. It depends on sample depth and shows how much a chronology is dominated by individual tree signals rather than by a coherent stand level signal. EPS threshold values are subjective. Similar to EPS, although even more dependent on the sample size, signal-to-noise ratio quantifies the strength of an observed common high-frequency signal among trees in the chronology. First-order autocorrelation shows the influence of previous year's growth on current year's growth $[34,36,90-93]$.

\subsection{Climate Data}

We used the University of East Anglia Climatic Research Unit (CRU) Time-Series (TS) 4.00 climate dataset [94,95]: mean temperature, maximum (actually mean maximum) temperature, minimum (actually mean minimum) temperature, and precipitation (monthly sums) for the period 1901-2012. In addition, we made use of the drought indices one- and three-month SPEI (Standardized Precipitation-Evapotranspiration Index) [96] based on CRU data which are commonly applied to monitor drought conditions. SPEIs, calculated over periods of different time scales, support the identification of cumulative periods that cause water deficits. We used the CRU TS google earth interface [97] to examine which instrumental records contribute to the grid cell data. All gridded datasets at $0.5^{\circ}$ spatial resolution were accessed by Koninklijk Nederlands Meteorologisch Instituut (KNMI) Climate Explorer [98], and the means of two grid cells closest to the site (extending from $27.5^{\circ}$ to $28^{\circ} \mathrm{N}$ and $86^{\circ}$ to $87^{\circ} \mathrm{E}$; Figure 1) were calculated. These cells cover roughly the extent of the Rolwaling valley. The inclusion of further neighboring cells decreased the tree growth-climate correlation coefficients, most likely due to less elevated terrain in the southern grid row and Trans-Himalayan position of the northern grid row.

To investigate temporal changes of local climate, we fitted nonparametric local polynomial regressions (LOESS) to monthly precipitation sums and monthly mean temperatures to visualize potential non-linearity of the trends during the entire period analyzed (1901-2012). The fitting and plotting was done with the scatterplot() function of the car 2.1-5 package [99] in $\mathrm{R}$ 3.4.1 [100]. We calculated monthly and yearly differences of mean temperature and precipitation sums between the means of the first and last 30 years of the investigated period (1901-1930 vs. 1984-2012) to gain information on the intensity of climate change represented by the CRU data.

\subsection{Tree Growth-Climate and BI-Climate Correlations}

To analyze the relationships between the standardized TRW and BI chronologies and the climate variables, we calculated Pearson's correlation coefficients and confidence intervals by using a stationary bootstrapped correlation function with optimal block length selection [101,102]. We calculated correlations for all months and seasons from previous year's May (first month of the previous growing season) to current year's September (last month of the current growing season) at a level of significance of $p<0.05$. Climate conditions of the previous year can pre-condition trees physiologically and may affect biochemical processes and tree growth of the current season [34]. Since climate data were available from 1901 onwards, and to refer to previous growing seasons, the correlations were calculated for the 1902-2012 period. In the first year of correlations (1902), chronologies contained 42 TRW and 18 BI series originating from 27 and 14 trees, respectively, which in both cases constitute the lowest replications for the studied period.

We calculated static correlations of TRW and BI with mean, mean minimum and mean maximum temperatures, precipitation sums, and SPEI for single months and seasons. To examine the stability of correlations for the analyzed period, we calculated 31-year moving window correlations [103] with one year offset between consecutive windows of TRW and BI.

Moving window correlations were computed for monthly mean temperatures and precipitation sums. While moving windows are suitable to detect the presence of stable periods over a range of time, evolutionary interval correlations reveal the lengths of specific periods [103]. To find the lengths 
of most recent periods with stable correlations, we used backward evolving window correlations with an initial window size of 31 years that increases in one-year steps starting from 2012 backwards. All correlation analyses were computed with the $d c c()$ function of the treeclim 2.0.0 package [104] in R 3.4.1 [100].

\section{Results}

\subsection{CRU Climate Data Trends}

Temperature trends were positive in all months of the period 1901-2012 (Table 1), however, the intensity of the increase changed over time (Figures 3 and A1). The annual mean temperature of the last 30 years of our TRW chronology $(1982-2012)$ was $0.87^{\circ} \mathrm{C}$ warmer than the first 30 years of the investigated period $(1901-1931, p<0.05)$. The temperature was significantly stable in June and July $\left(+0.44{ }^{\circ} \mathrm{C}\right.$ and $+0.05{ }^{\circ} \mathrm{C}$, respectively; $\left.p<0.05\right)$, while the increase was significant and most pronounced in November and December (both $+1.56^{\circ} \mathrm{C}, p<0.05$ ). Additionally, winter season (DJF, $+1.31^{\circ} \mathrm{C}, p<0.05$ ) and pre-monsoon season (MAM, $+0.89^{\circ} \mathrm{C}, p<0.05$ ) temperatures increased significantly. The changes did not proceed linearly (Figures 3 and A1): after an increase until the mid-20th century, temperatures stagnated or decreased slightly, followed by an increase beginning from ca. the 1970s until the end of the investigated period in 2012. This pattern was obvious in all months except February and July. February temperatures increased linearly. By contrast, July temperatures showed a slight decrease during the first part of the period, followed by a more pronounced increase towards the 21 st century.

Table 1. Differences between means of precipitation sums and mean temperature of the periods 1901-1931 and 1982-2012 for single months and the entire year.

\begin{tabular}{ccc}
\hline & Mean Temperature $\left({ }^{\circ} \mathbf{C}\right)$ & Precipitation $(\mathbf{m m})$ \\
\hline January & $1.07^{*}$ & 4.68 \\
February & $1.32^{*}$ & -4.74 \\
March & $1.36^{*}$ & -9.88 \\
April & $0.79^{*}$ & 6.40 \\
May & $0.53^{*}$ & $44.73 *$ \\
June & 0.44 & $-78.10^{*}$ \\
July & 0.05 & 42.82 \\
August & $0.41^{*}$ & $-103.49 *$ \\
September & $0.37^{*}$ & -2.17 \\
October & $0.97^{*}$ & 3.83 \\
November & $1.56^{*}$ & -3.44 \\
December & $1.56^{*}$ & 8.01 \\
Year & $0.87^{*}$ & -7.25 \\
\hline Note: Asterisk indicates significant differences at $p<0.05 ;$ data source: CRU, see Section 2.
\end{tabular}

Precipitation values of all months have fluctuated over the investigated period without any clear trend (Figures 3 and A2). Comparing the first and last 30 years of the investigated period, annual precipitation did not change significantly $(p<0.05)$. However, monthly precipitation sums showed trends in different directions: they increased significantly $(p<0.05)$ in May $(+45 \mathrm{~mm})$ and decreased in June $(-78 \mathrm{~mm})$ and August $(-104 \mathrm{~mm})$. Changes in other months were not significant (cf. Table 1). Due to the high interannual variability of monthly precipitation sums, periods of different trends are less distinctly visible in comparison to temperature. However, the non-parametric regressions showed two or three trend segments for most months (cf. Figures 3 and A2). The last directional change of the trends occurred during the second half of the 20th century, at ca. 1970. The changes in temperature and precipitation trends are also reflected by SPEI trends. 

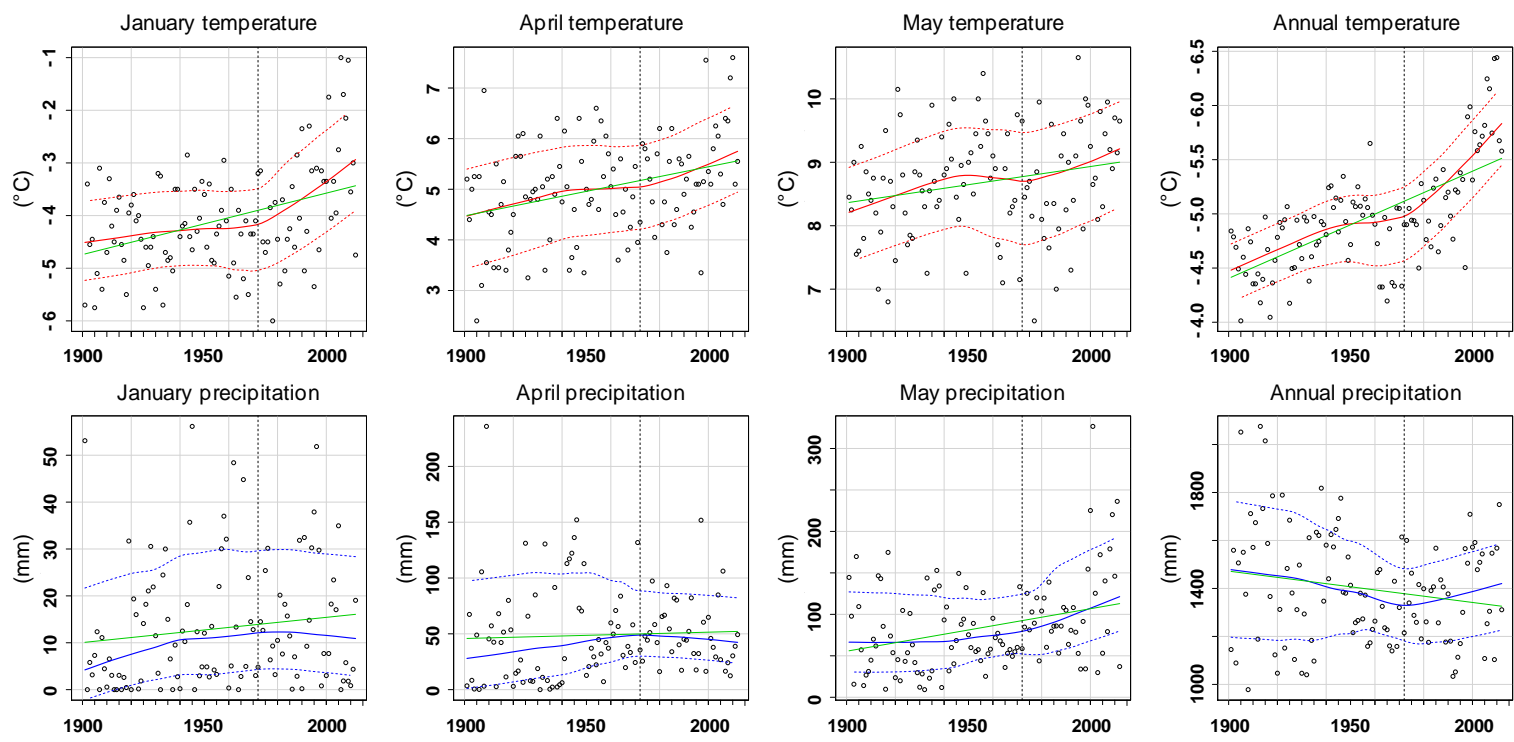

Figure 3. Monthly (January, April, and May; see Figures A1 and A2 for all months) and annual CRU TS 4.0 mean temperature and precipitation sums: non-parametric trends 1901-2012 of the study area. The solid and dashed red lines show locally weighted scatterplot smoothing (LOESS) and corresponding spread smooths, respectively. For comparison, the green line illustrates a linear regression. The dashed black line indicates 1972, i.e., the first year of the period that was analyzed by static tree growth-climate correlations.

\subsection{TRW and BI Chronologies}

The span of the TRW and BI chronologies (Figures 4 and 5) ranged from 1748 to 2012 and 1819 to 2012, respectively. Distinct growth reductions occurred in TRW in 1818, 1891, 1906, 1968, and 1999 (Figure 4), and in BI in 1820, 1838-1841, 1850, 1862, and 1962 (Figure 5). Running EPS of TRW chronology was greater than the arbitrary [93] threshold of 0.85 in all periods except the first one centered upon 1840 with EPS of 0.61 (Figure 4). In case of BI chronology EPS was $<0.85$ in the periods centered upon 1865, 1880, 1925, and 1940 (Figure 5). Running R-bar changed in course of the TRW chronology and ranged from 0.19 in the period centered upon 1930 to 0.58 in the period centered upon 1870 (Figure 4). In the case of BI, R-bar ranged from 0.08 in the period centered upon 1940 to 0.35 in the 1865 period (Figure 5). The static descriptive statistics of TRW and BI chronologies are presented in Table 2.

Table 2. Descriptive chronology statistics.

\begin{tabular}{ccccc}
\hline & $\begin{array}{c}\text { TRW Chronology } \\
\text { Interval 1748-2012 }\end{array}$ & $\begin{array}{c}\text { TRW Correlation } \\
\text { Analyses Interval } \\
\mathbf{1 9 0 2 - 2 0 1 2}\end{array}$ & $\begin{array}{c}\text { BI Chronology } \\
\text { Interval 1819-2012 }\end{array}$ & $\begin{array}{c}\text { BI Correlation } \\
\text { Analyses Interval } \\
\mathbf{1 9 0 2 - 2 0 1 2}\end{array}$ \\
\hline $\begin{array}{c}\text { Mean sensitivity } \\
\text { Mean R-bar }\end{array}$ & 0.099 & 0.082 & 0.024 & 0.019 \\
$\begin{array}{c}\text { First-order autocorrelation } \\
\text { Mean expressed }\end{array}$ & 0.324 & 0.337 & 0.217 & 0.176 \\
population signal (EPS) & 0.696 & 0.671 & 0.522 & 0.436 \\
Signal-to-noise ratio & 0.910 & 0.947 & 0.853 & 0.903 \\
\hline
\end{tabular}

NA: not available. 


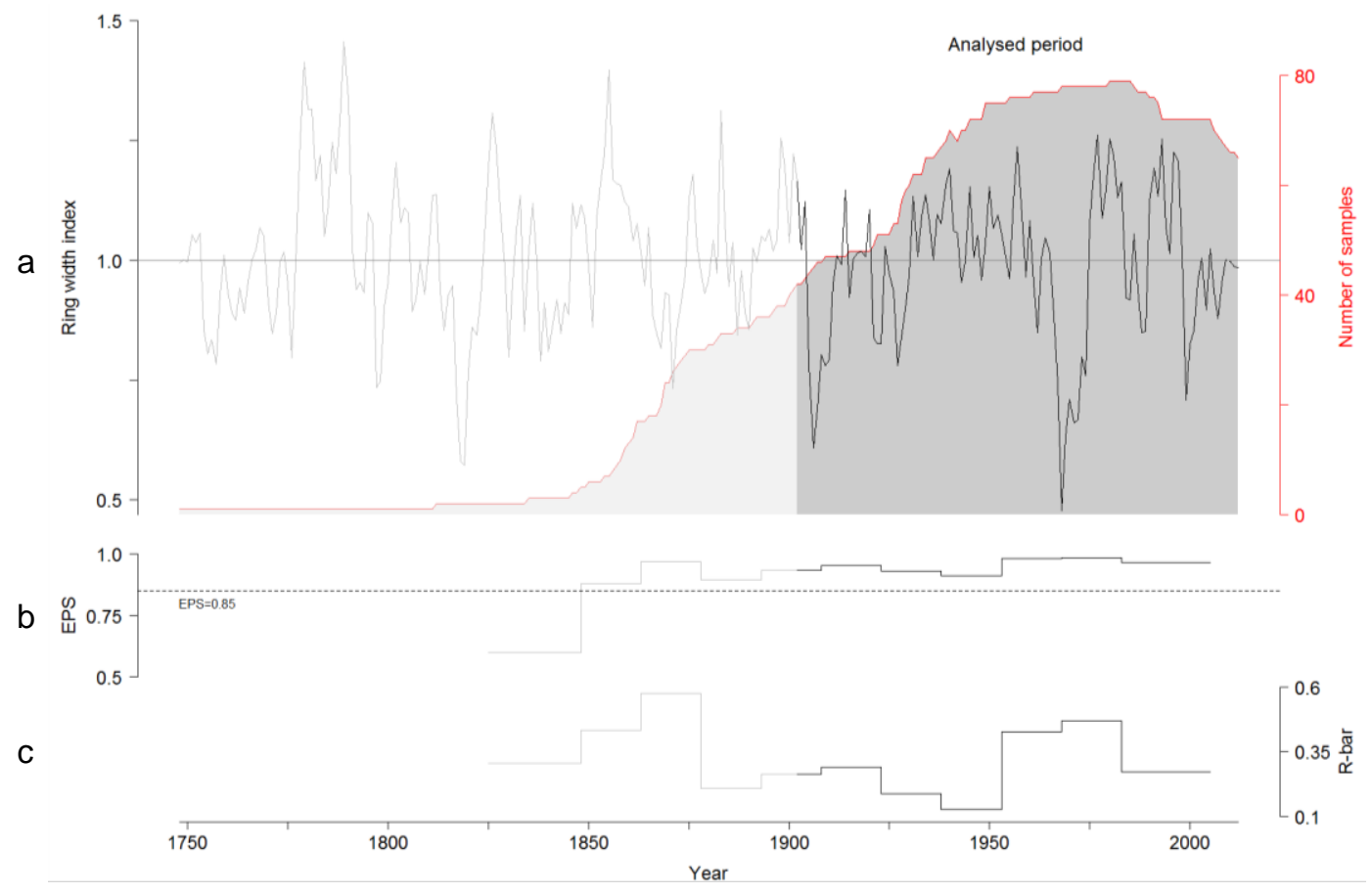

Figure 4. Tree-ring width standard chronology (black curve) and sample depth (red curve) (a); and corresponding EPS (b) and R-bar values (c). The lighter sections of the graphs show the part of the chronology that was not used for tree growth-climate analyses.

a

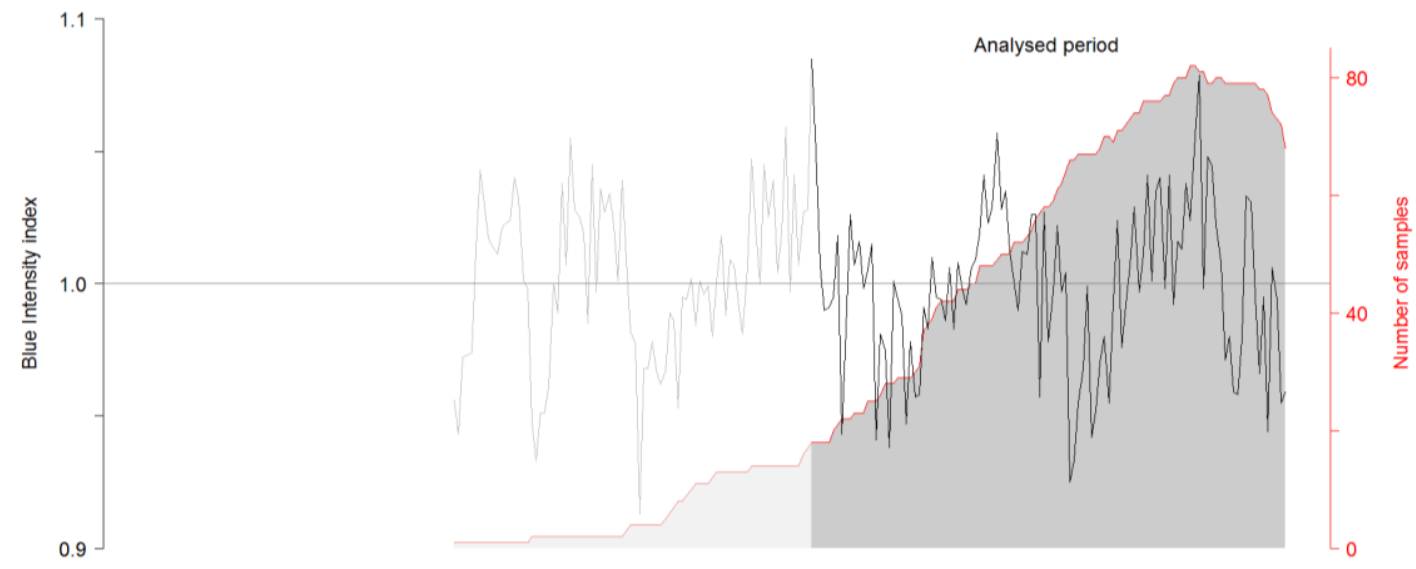

b



C

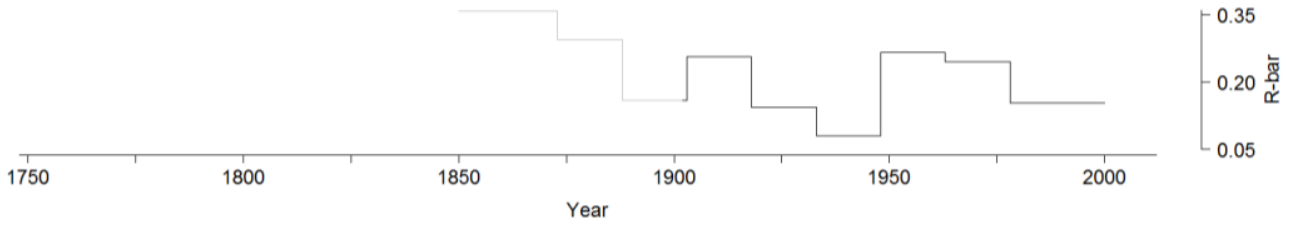

Figure 5. Blue Intensity standard chronology (black curve) and sample depth (red curve) (a); and corresponding EPS (b) and R-bar values (c). The lighter sections of the graphs show the part of the chronology that was not used for BI-climate analyses. 


\subsection{Moving and Evolving Window Correlations of TRW and BI Chronologies with Climate in the Period} 1902-2012

Since we found rather weak static TRW-climate and BI-climate correlations for the entire investigated period (Figure A3), we tested the temporal stability of correlations by applying 31-year moving windows with a one year offset to compare both proxies. Both TRW and BI showed distinct changes in correlations with mean temperature and precipitation over time for the 1902-2012 period.

\subsubsection{Moving TRW-Climate Correlations}

The interdependence of TRW and climate variables alternated during the investigated period at least once from positive to negative correlation or vice versa. Phases with significant correlations without these alternations did not exceed ca. 50 years, and most of the periods were distinctly shorter. To characterize the changes, we consider periods of at least four consecutive significant 31-year windows.

There was a period of positive correlations of TRW and summer temperature (August: 1941-2001; June: 1940-1976). Negative correlations of TRW and temperature occurred in spring (February to May) from the beginning of the 1970s until the end of the investigated period (2012, cf. Figure 6).

TRW and March precipitation correlated negatively during the mid-20th century. This relation inverted and shifted by one month, resulting in a positive correlation of TRW and April precipitation from 1972 until the end of the investigated period. TRW and July precipitation correlated negatively at about the same time. In addition, there were several significant correlations of TRW and previous year's climate variables (cf. Figure 6). In summary, both TRW-temperature and TRW-precipitation moving windows showed a fragmented pattern of significant tree growth-climate relationships with long insignificant phases.

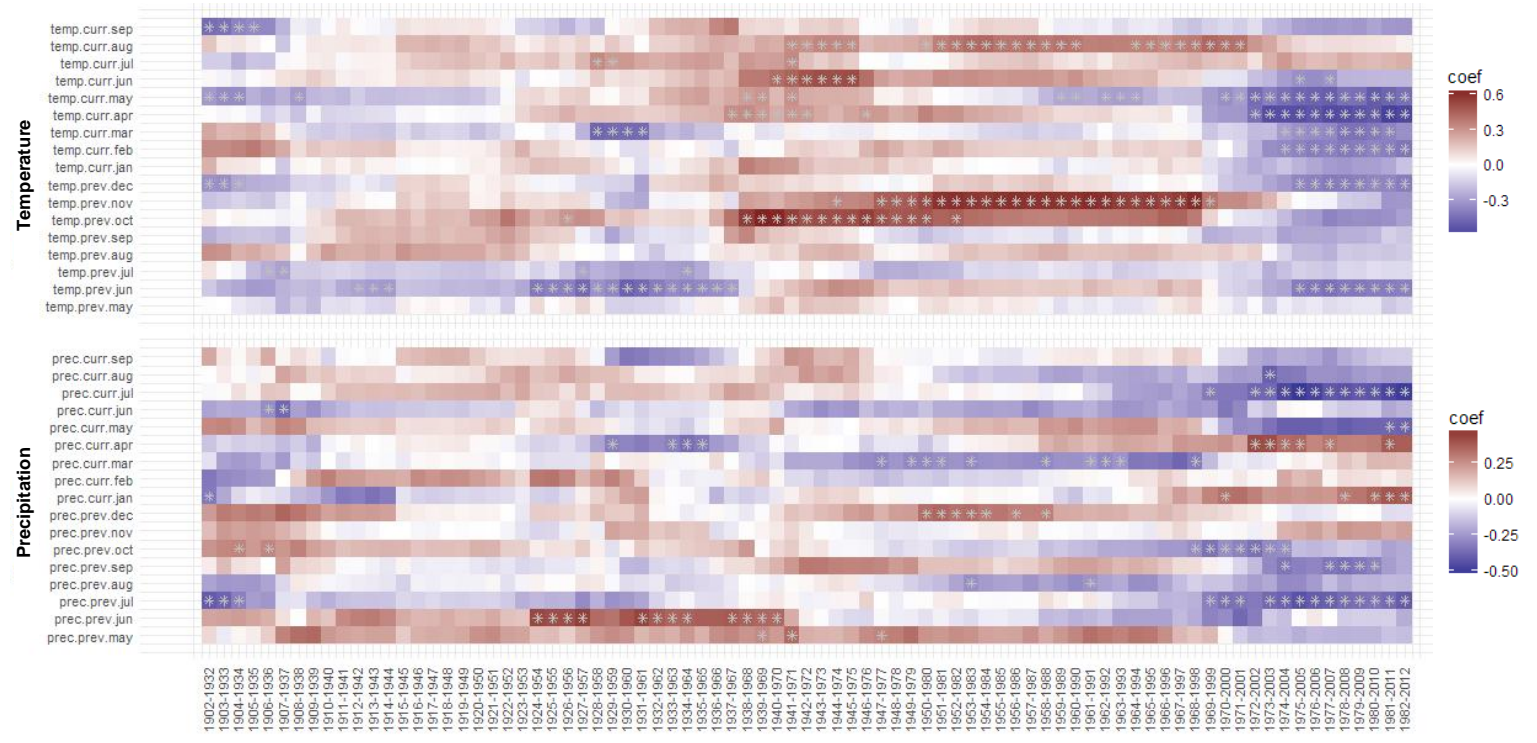

Figure 6. Tree-ring width chronology-mean temperatures and tree-ring width chronology-precipitation sums moving window correlations. Periods with asterisk indicate significant $(p<0.05)$ correlations.

\subsubsection{Moving BI-Climate Correlations}

The BI-temperature correlations showed a more stable, less fragmented pattern in comparison to TRW-temperature relations (Figure 7): there were long periods of rather strong positive BI-temperature correlations in all months of the current growth year except January and July. This pattern lost strength and significance from the ca. 1970s onwards, and current January and February showed windows with negative BI-temperature correlations from 1976 until the end of the investigated period. 
The correlations of BI with precipitation showed a smaller number of significant periods (Figure 7): from 1927 to 1976 BI and September precipitation correlated positively. This relation was replaced by a negative BI-August precipitation correlation lasting from 1946 to 1990. Negative correlations of BI and precipitation occurred in late spring and summer (May, June: 1978-2012, July: 1969-2003). In addition, there were several significant positive correlations of BI and previous year's climate, especially temperature, with the longest and most significant ones in November and December (cf. Figure 7). In summary, a similar change in BI-climate correlations as in the case of TRW in the second half of the 20th century is obvious, however, without reaching comparable significant correlation coefficients during the period after 1970s.

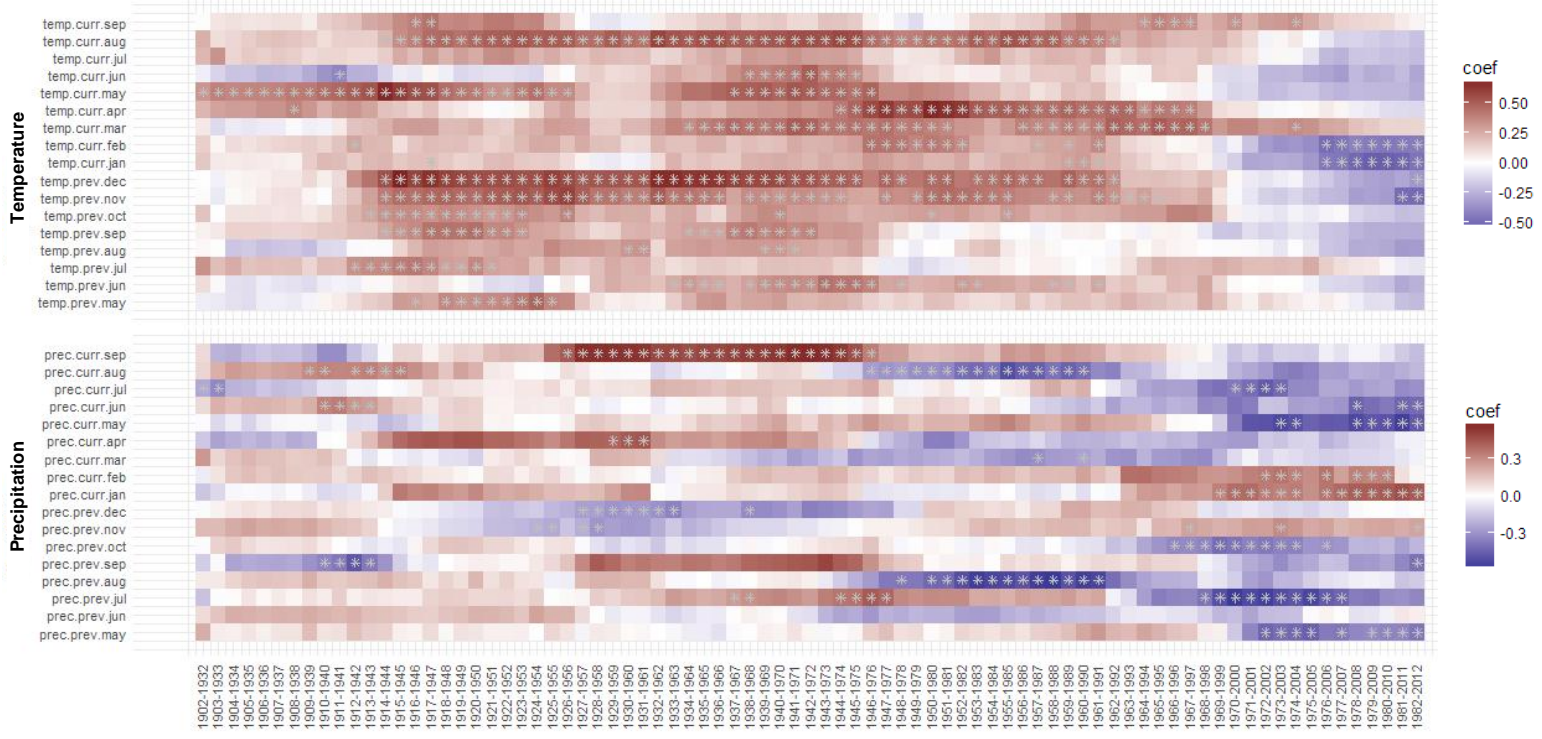

Figure 7. Blue Intensity chronology-mean temperatures and blue Intensity chronology-precipitation sums moving window correlations. Periods with asterisk indicate significant $(p<0.05)$ correlations.

\subsection{Static Correlations of TRW and BI Chronologies with Climate in the Period 1972-2012}

\subsubsection{Static TRW-Climate Correlations}

Radial growth, measured by TRW, and climate variables showed continuously strongest correlations towards the end of the investigated period. Evolving windows of TRW-climate and BI-climate relations (Figures A4 and A5) showed that the stable periods from 2012 backwards differ in length, depending on the considered combination of climate variable and month. On average, 1972 was identified as the onset of the phase of stable correlations. Thus, it can be considered to represent the beginning of the most recent era of Abies spectabilis TRW and BI (see Section 3.4.2) in our study area.

We found significant static correlations of TRW with climate variables mainly during winter and spring for both single months and seasons of recent decades (Figure 8 ). The correlation analyses showed a significantly negative relationship between radial growth and mean $(r=-0.46)$, minimum $(r=-0.38)$ and maximum temperature $(r=-0.47)$ for the current year's pre-monsoon season (March-May). Moreover, we detected significant negative correlations of mean $(r=-0.32)$ and maximum $(r=-0.35)$ temperature during winter prior to the current growing season (December-February) (Figure 8).

Precipitation sums and TRW correlated significantly positively during current January $(r=0.31)$ and April $(r=0.35)$. The current monsoon season (June-August) exhibited a significant negative correlation of radial growth and precipitation sum $(r=-0.33)$ (Figure 8). We found significantly positive correlations of TRW to one-month SPEI variables (January: $r=0.27$, April $r=0.33$ ) (Figure 8) pointing to pre-monsoon moisture sensitivity, in line with the relations of TRW to temperature and precipitation. 


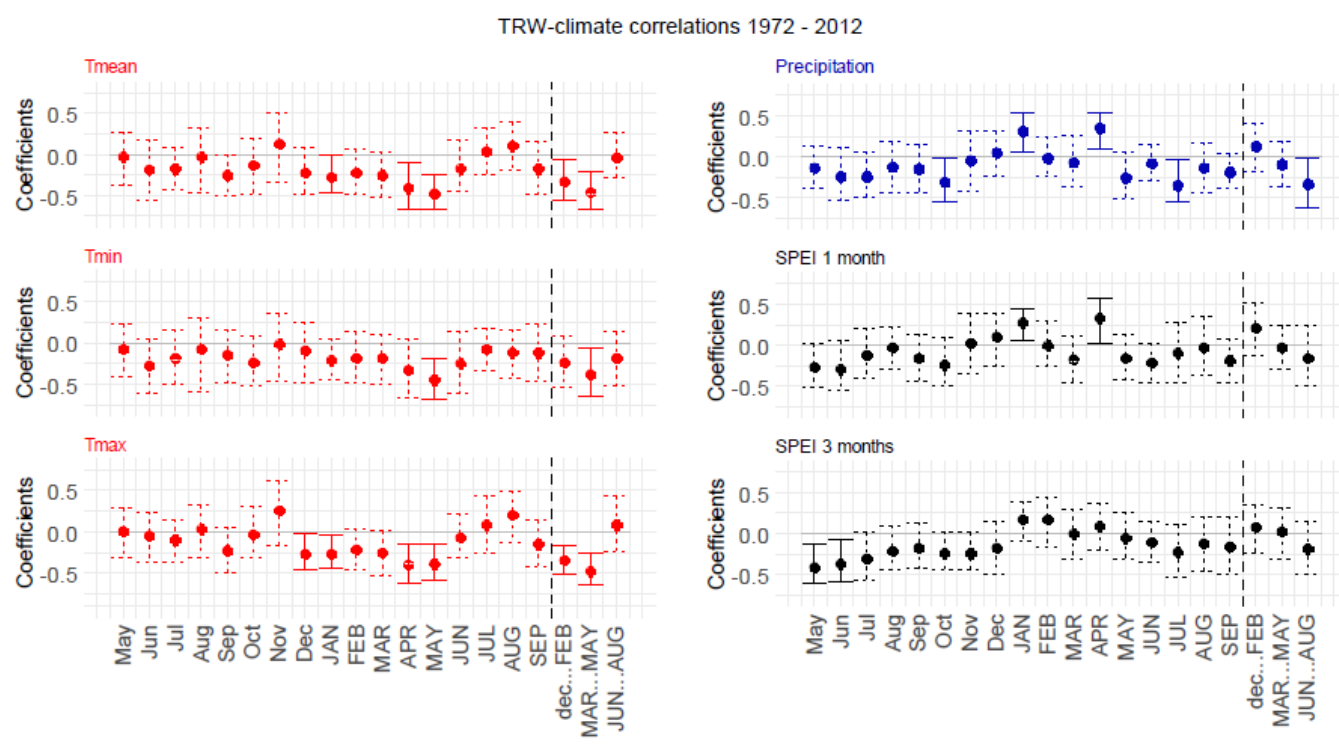

Figure 8. The 1972-2012 static correlations of the tree-ring width chronology with temperature, precipitation and drought indices for current and previous year's months and current year seasons. Solid bars indicate significant correlations $(p<0.05)$.

\subsubsection{Static BI-Climate Correlations}

Compared to TRW, BI exhibited similar correlations to temperature (Figure 9). Winter season prior to growing season (December-February) showed negative correlations of BI with mean temperature $(r=-0.43, p<0.05)$, also reflected in minimum and maximum temperature correlations of single months. In addition, we found negative correlations of BI with mean and minimum temperatures of the single months of the pre-monsoon period and the whole monsoon season of the current year (e.g., May mean temperature $r=-0.28$, June to August minimum temperature: $r=-0.43$ ).

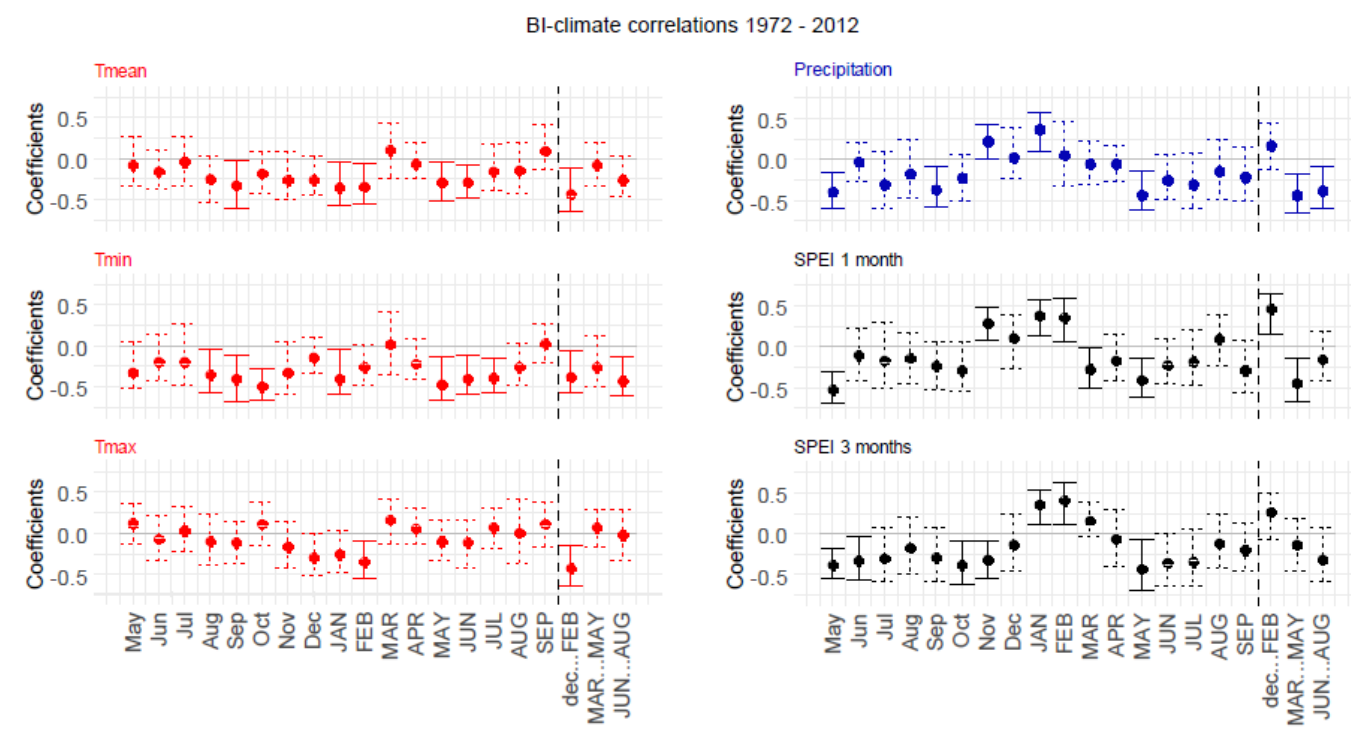

Figure 9. The 1972-2012 static correlations of the Blue Intensity chronology with temperature, precipitation and drought indices for current and previous year's months and current year seasons. Solid bars indicate significant correlations $(p<0.05)$.

The January precipitation influenced BI positively $(r=0.36)$ (Figure 9). There was a strong negative correlation of BI with precipitation during the pre-monsoon ( $r=-0.44$; March-May) and monsoon 
( $r=-0.38$; June-August) periods. BI showed a positive relationship with the one-month SPEI drought index during winter season ( $r=0.46$; December-February), confirmed by correlations of one- and three-month SPEI during single winter months. In contrast to TRW, there was a negative relation of BI and moisture in May and pre-monsoon season (Figure 9).

In summary, these results indicate that both radial growth and BI were influenced positively by low temperature in winter and spring prior to the current growing season. Radial tree growth was influenced positively in years with high precipitation in current January and April and low rain intensity in July. BI results were similar in winter; however, they differ in pre-monsoon and monsoon seasons (Figures 8 and 9). It is particularly remarkable that the results are different from those obtained for the 1902-2012 period (cf. Figure A3).

\section{Discussion}

\subsection{TRW and BI Chronologies}

TRW and BI chronologies' descriptive statistics coincidentally indicated their applicability for climate correlations. The chronologies' mean sensitivity showed low interannual variability, an inherent characteristic of Himalayan humid environment TRW chronologies (e.g., [11,33,105]). Mean R-bar values showed a rather low common signal throughout the chronology, pointing to a rather poor agreement between single series. However, this is also a common characteristic of Himalayan chronologies $[11,27,106]$. The running $R$-bar values varied distinctly over time and the low values in some periods might point to ecological disturbances or stand dynamic processes [36]. The study site is to our knowledge virtually free from direct human intervention. Thus, any disturbances are of natural origin. According to the running EPS values, the chronologies reliably represent the population signal during the entire period that was subjected to growth analyses $[90,93]$. The autocorrelation values showed that the current year's tree growth was influenced by physiological effects that originate in the previous year [34]. The growth reductions in the TRW chronology in 1818 might be connected to the Mount Tambora eruption in 1815 [24], the reductions in 1968 and 1999 coincide with winter droughts in Nepal [107,108], while the reduction in 1906 followed upon an extreme weak monsoon epoch [109].

\subsection{Tree Growth-Climate Relationships during Recent Decades (1972-2012)}

Our results for the period with most stable correlations (1972-2012) suggest that Abies spectabilis tree growth was sensitive to temperature induced moisture deficits during the pre-monsoon season. We found a negative relationship between radial tree growth and spring temperature, indicating a negative relation of growth with evapotranspiration, which is enhanced by temperature. In addition, the positive correlation of TRW and precipitation of April points to moisture sensitivity during spring [34]. This result is in line with several previous studies on Abies spectabilis growth patterns $[11,12,24,32,33,59,65,110,111]$ and those of other coniferous species from sites in the Himalaya and the Tibetan Plateau [58,105,112-115]. Compared to the present study, correlation coefficient values of the aforementioned studies were mostly in a similar, rather low range.

Studies of other tree species in the Himalaya exhibited comparable results. For instance, Ren et al. [116] showed the direct dependence of the onset of xylogenesis of a Juniperus species on late spring precipitation. Betula utilis, a broadleaved species, showed a positive correlation with spring precipitation and a negative one with spring temperature $[8,9,117]$. In contrast, Shrestha et al. [28] showed negative influence of May precipitation on Abies spectabilis radial increment at a treeline site further west (Langtang National Park). The difference might be attributed to anthropogenic disturbance in Langtang and/or differing micro-climate conditions.

In line with our results, Kharal et al. [111] reported a negative correlation of Abies spectabilis tree growth and previous year's December temperature. Several other studies showed relationships to winter temperatures which differ from ours, such as positive correlations of Abies spectabilis radial growth, linked to freezing stress and other related processes $[10,30,31,110,118]$. Similarly, 
Borgaonkar et al. [113] and Sohar et al. [59] showed a positive relationship to winter temperatures for two conifer species in the western Himalaya.

Results on tree growth-climate relationships at our site during early and mid-20th century more or less corroborate those of other studies highlighting current summer and previous year's autumn temperatures as main limiting factors of Abies spectabilis' radial increment $[10,12,28,29,110]$. These studies used climate records of differing origin and length (station, 1978-2007 [28]; CRU, 1947-2006 [29]; CRU, 1901-2011 [10]; station, 1959-2004 [110]; station, 1970-2013 [12]), exacerbating comparability and causing differences in the temporal variability of correlations cf. [28,29,59], this study.

Tree-ring width correlated positively with January precipitation in our study area. This finding is contrary to results that point to a negative impact of winter moisture availability on the radial tree growth in central Nepal $[11,28,31]$. The reported negative impact might be a consequence of deeper snowpack that retards the melting process and the soil temperature increase in spring, resulting in a delayed onset of cambial activity $[19,119]$. Other studies did not assess a negative relation of snow precipitation and following growing season tree growth (e.g., $[65,120])$. Once melted, snow precipitation might contribute to moisture availability during the dry spring season months $[18,19,28,29]$. The results of TRW-one-month SPEI correlations show growth limitation due to soil water content deficits in January and April, underpinning the results from correlations of TRW with temperature and precipitation. The significant one-month SPEI correlation points to a short cumulative period of water deficit [121] due to excessive monsoon precipitation occurring each year, resulting in high available water capacity during summer and autumn [18].

In contrast to spring drought-related relationships, we found a significantly negative correlation of radial growth with monsoon season (JJA) precipitation. These results are consistent with those from two rather dry sites located in the Mustang and Manang regions of Nepal [11,111]. The central Himalaya receives the majority of annual precipitation during summer season. The amount of water is by far sufficient to saturate the soil water content, and to cover the water demand of the vegetation, even in years with relatively low amount of precipitation. Thus, we suggest that the negative correlations might indicate that precipitation acts as a proxy for cloud cover and light conditions, respectively, influencing tree growth [122]. If the cloud cover is reduced, trees receive higher insolation, causing enhanced assimilation processes and radial growth. At the same time, the impact of insolation on air temperature might be reduced due to the energy-consuming evaporation process. These linkages might inhibit the TRW-summer temperature correlations to reach the level of significance, while the improved light conditions enhance radial growth, resulting in significantly negative correlation with precipitation.

In contrast to other studies $[10,28,29,110]$, we did not find a significant correlation of TRW with temperature or precipitation of the previous growing season (May-September). Nevertheless, the high first-order autocorrelation value of the TRW chronology points to a distinct influence of previous year's tree growth on current year's growth $[34,115]$. The negative correlation of TRW with October and September precipitation might indicate a physiological preconditioning for the following year [34]. Reduced precipitation and subsequent higher irradiation might enable trees to gain more carbon and/or cause a larger starting size of the cambial zone for the following year [34,122]. However, this result should be carefully interpreted as we assume the period of cambial activity to end before or early in October according to measured soil and air temperatures [82,123].

In summary, a rather wide spectrum of different radial growth-climate relationships exists at regional and local scales within the Himalayan region of Nepal. With regard to spring moisture sensitivity, our results largely correspond to results of other studies from sites in Nepal and different Himalayan regions. However, some of the published results, including those from study sites near to ours, showed differing relations of tree growth with temperatures and precipitation of the winter prior to growing season. The general east-west precipitation gradient in the Himalaya [124] does explain variations in tree growth-climate relations to a limited extent only. In line with several previous studies $[11,28-31,58,59,125]$, we assume that deviating results are caused by local variations 
of the heterogeneous environment, which are not captured by sparse (and rather short) records of climate data from high elevation sites or derived gridded data [126]. Moreover, spatially differing characteristics of climate factors at local and regional scales need to be considered when drawing generalized conclusions. For instance, the date of monsoon onset affects radial increment in different intensity at dry and wet sites [28]. Finally, soil conditions, micro-topography, light conditions, land use and other site factors might be reasons for differences in tree growth-climate relationships.

\subsection{Changing Long-Term Tree Growth-Climate Relationships (the Entire 20th Century)}

The static correlation of the whole CRU data period (Figure A3) showed rather low correlation coefficients, in line with previous studies from the Himalaya (e.g., [10-12]) and other regions [106,127].

The reliability of growth-climate correlation results depends inter alia on the quality of climate data. The warming trend during the 20th century is well reproduced by the gridded CRU climate data used in our study. However, the Rolwaling CRU spring precipitation data might obscure difficulties in modeling precipitation data for complex terrain [78,128] as negative trends of station data [3] and reconstructions $[33,115,129,130]$ for the western and central Himalaya during spring of recent decades are not visible. Since the CRU climate data are based on station data [94,131], length and quality of sparse local climate data records from the region might influence tree growth-climate correlations. The CRU methodology includes measures to produce high quality data in regions with sparse instrumental records. Despite these efforts, the combination of only few stations with long continuous records in vicinity of the grid cells and complex terrain might induce non-significant tree growth correlation results, especially in early periods.

The increase in availability and in quality of station data from Nepal at finer spatial resolution since the 1960s [132] coincides with the beginning of the stable correlation period. Thus, the increasing data quality could play a certain role regarding more stable tree growth-climate relationships during recent decades [59]. However, CRU data are widely used in dendroclimatological studies (e.g., [106,133]), also in mountain regions $[54,127,134,135]$ including the Himalaya $[10,29,58,59,136]$ and their use is recommended for regions with sparse cover of stations despite certain limitations [137].

The detrending method could potentially cause a putative divergence phenomenon [88]. In our study, while using a smoothing spline method for detrending, each individual series was evaluated to preserve low frequency variability but to avoid the artificial increase of the index values of the last years of the chronology. Moreover, the comparison of moving window correlations of tree-ring data detrended in different ways showed no substantial differences (see Figure A6). Thus, we rule out "detrending end effects" as origin of unstable correlations.

Age effects and microsite differences could also cause unstable tree-ring width-climate correlations [46]. Consistent with unstable tree-ring width-climate correlations, the TRW signal strength ( $R$-bar) alternated during the period 1902-2012. These variations in $R$-bar over time might indicate disturbances [36] or modulations of the relationships by, e.g., tree age or spatially varying environmental variables such as soil properties and light conditions $[138,139]$.

Changes of the tree growth-climate relationships over time could also point to differentiated responses of groups of trees to climate (e.g., younger vs. older individuals). After splitting the chronology into subsets with old trees (minimum age of 100 years) and young trees, we found similar unstable radial growth-climate correlations for each subset as for the chronologies with all trees of any age (Figures A7 and A8). In addition, the individual tree response to climate (not presented here) is similar to those of the standard chronologies. Thus, temporal changes of the tree growth-climate relationship do not originate from such differences in tree age.

However, despite the cores originate from one site there might be finer-scaled differences of age structure of trees and their relation to climate caused, for instance, by small-scale spatial differences in soil temperature and soil moisture [82]. Small-scale fire, insect outbreaks and geomorphic events or age-related tree deaths might cause disturbances, contributing to variation in tree response. Differences 
in intra- and inter-specific competition for nutrients or light could also result in varying tree responses. All these environmental factors could cause variance in tree growth which is not explained by climate.

Although effects of non-climatic factors cannot be ruled out, we assume climatic changes to be the root cause for unstable TRW-climate correlations. The observed instability of tree growth-climate correlations and their tendency towards negative relation with temperature and towards moisture sensitivity corroborate various reported divergence phenomena from high latitudes and mountainous environments (e.g., $[38,42,46,51,54,140,141]$ ). In the Himalaya, only few studies with significant long-term correlations exist. A dendroclimatic study of Pinus smithiana (Wall.) Boiss showed stable negative correlations with spring temperature for the whole analyzed period from the end of 19th to the beginning of 21st century [58]. Sohar et al. [59] found unstable dendroclimatic signals of Abies spectabilis growth in the western Himalaya during the CRU data period with climate change effects and potential inaccuracies in the CRU data as potential reasons. However, stable periods do not match with those of the present study. Shrestha et al. [28] showed unstable Abies spectabilis and Pinus wallichiana A. B. Jackson growth-climate relationships for central Himalayan sites with climatic changes as potential causes for instability. Here, a comparison to our results is complicated by differing window sizes and length of investigated periods. Most studies correlated tree growth and climate over shorter periods of time, based on availability of local station data or chronology length (30-60 years), and did not test correlation results for stability $[10,11,28,29,32,33,110,111,115,142]$.

According to the results of our moving correlations, we assume that Abies trees have become more climate-sensitive during the reinforced climate warming period beginning in the 1970s. Similar to the alterations of radial tree growth-climate correlations and of its signal strengths, the climate changed non-linearly, with a temperature increase in the early 20th century, a stable phase during the mid-20th century and pronounced warming during the last decades of the 20th and the beginning of the 21st century. The period of stable climate conditions coincides with a positive relationship of TRW to summer temperature and a negative one to March precipitation, pointing to sufficient moisture availability in spring and growth limitation mostly by low summer temperature. During the climate warming phase earlier in the century, the negative relation of tree growth and May temperature indicated moisture sensitivity. This signal was less significant as during the ca. last 40 years of the investigated period, but already apparent. We suppose that the climate warming-induced increase in evapotranspiration and the consequently intensified moisture stress triggered a shift from summer temperature to spring moisture limited growth response and the stabilization of the correlations towards the end of our investigated period. This is consistent with the change in temperature (Figure 3) and SPEI trends of the study area and intensified spring droughts in the central Himalaya during recent decades [115]. Thus, increased drought might have caused the divergence in growth-climate relationships as observed in other studies $[53,143,144]$, with Abies spectabilis trees showing growth plasticity towards the changing environment as other coniferous species do (e.g., $[46,48,133,145]$ ). Obviously, this potential adaptation contributed to the rather low responsiveness of the Rolwaling treeline to climate warming [73], and may be crucial for its future sensitivity to climate change.

Until the end of the period of relative stable climate conditions in the mid-20th century (Figure 3), tree growth was limited by previous winter and current spring and summer temperature, and related inversely to winter precipitation and snow height, respectively (Figure 6). These linkages were also found in some studies for the period after the mid-20th century [11,28,31]. Moreover, stable correlations for the whole 20th century exist for a negative relation of tree growth to spring drought [58] as well as for a positive relation to summer temperature [10]. Obviously, some studies neglected information of specific periods or individual trees by the static analysis [48], and/or there might be sites, where climate warming has reached or not reached the potential threshold [43] towards temperature-induced moisture deficits during pre-monsoon season. 


\subsection{Suitability of Blue Intensity as a Climate Proxy}

On the surface, BI-climate correlations exhibited similarities in comparison to correlations of TRW. In detail we found significant differences. BI yielded slightly lower climate correlation coefficients in case of static correlations, but the BI-climate relationships turned out to be generally more stable over time. In line with TRW correlations, BI showed an unstable temporal pattern of climate correlations, however, there were distinctly longer, more significant stable periods. As in the case of TRW-climate correlations, the BI-climate relationships changed towards positive relations with spring precipitation and negative with spring temperature towards the end of the investigated period. This change, however, was less pronounced, and occurred later in comparison to TRW. BI static correlations for the recent four decades did not show spring moisture sensitivity, but a negative relationship to winter and summer temperatures as well as to spring and summer precipitation.

BI correlated positively to spring and summer temperature during a long period, covering nearly the entire 20th century, in line with results of correlations between climate and maximum latewood density (MXD) of Abies spectabilis growing near treeline in far western Nepal [65]. The temperature of current year's August played an important role in both cases: MXD correlated positively with August and September temperature [65] while BI was in positive relation to temperatures of July and August. Similarly, Abies spectabilis MXD of a study in the NW Himalaya correlated amongst others with September temperature [59]. The slight differences in seasons might result from differences in natural settings between both study areas in terms of micro-climates, soil types, etc. The quality and length of climate data used to perform climate-growth investigations are different as well. Our positive temperature signal for spring and early summer during 20th century was not apparent in the MXD signal, but distinctly visible in correlations of mean and minimum density [65]. Most likely, the latewood formation at our site depends to a greater extent on temperature conditions and consequently carbon acquisition earlier in the year. In contrary to our results for the last decades, Sano et al. [65] did not find any significant correlation of MXD to precipitation. Given the temporal pattern of our correlations, this difference might be attributed to the fact that their MXD chronology ended more than ten years earlier.

Opposite to TRW, BI-climate correlations were not related to moisture conditions during spring. We assume that the formation of latewood cells occurs during the late growing season when moisture and temperature are sufficient. Moreover, latewood density is in general rather related to climate conditions of the entire growing season. BI might be limited by moisture availability in future since the moving window correlation pattern (Figure 7) showed that it already lost its previously positive relation to spring temperature. The different temporal patterns of the correlations of TRW and BI indicate the potential of BI to gain additional information on interannual growth patterns in relation to climatic conditions. Similar to MXD, BI is potentially more useful for climate reconstructions in comparison to TRW [66]. Using BI, additional knowledge could be obtained on, e.g., Abies spectabilis biomass acquisition.

\section{Conclusions}

Abies spectabilis growth-climate correlations in the Rolwaling valley changed during the 20th century, most likely to be attributed to intensified climate warming during the second half of the 20th century. In recent decades, Abies spectabilis radial growth has been mostly limited by moisture availability during pre-monsoon season. Winter and pre-monsoon seasons receive the smallest amount of annual precipitation, while sharply rising temperatures in spring increase evaporation, leading to enhanced drought stress when cambial activity starts after winter. Ongoing climate warming will aggravate droughts most likely affecting Abies spectabilis more adversely in future and challenging its plasticity.

Blue Intensity of Abies spectabilis was shown to be a climate proxy in this study for the first time. The BI signal was more stable and showed higher correlation coefficients compared to radial increment, 
especially with temperature during the 20th century. It was less affected by spring moisture sensitivity in comparison to tree growth.

Our results accentuate those of most other studies, but show also some differences. To detect underlying mechanisms for temporally and spatially varying results, further studies from different locations are needed to evaluate tree growth response to climatic variables in relation to small-scale climate data and other site properties (e.g., stand structure, gravitational mass movement, geomorphology, slope, aspect, and soil) and their variations. In addition, future studies should analyze individual growth responses to these factors to quantify strategies of single trees or groups of trees. However, the availability of data representing the local climate over sufficient time periods, especially precipitation characteristics of the mountainous terrain at high spatial and temporal resolution, will remain a major challenge.

Author Contributions: N.S., U.S., J.B., R.P.C. and T.S. conceived and designed the experiments; N.S., R.J.K. and K.J. performed the experiments and analyzed the data; and N.S. and U.S. wrote the paper with input from R.J.K., K.J., J.B., R.P.C. and T.S.

Funding: The contribution of Ryszard J. Kaczka and Karolina Janecka was supported by the NCN project DEC-2013/11/B/ST10/04764. This research was funded by the German Research Foundation for funding (DFG, SCHI436/14-1, BO 1333/4-1, SCHO 739/14-1).

Acknowledgments: We thank Ram Bahadur, Birgit Bürzle, Nina Kiese and Hanna Wanli for assistance in the field and Julika Hellmold, Aleksandra Ola Lewandowska-Duzy, Ravel Malanda and Hendrik Maaß for support in the lab. We are grateful to Ramchandra Karki for discussion on climate data. Thanks to Kathryn Leve and Claus Carstens for map preparation. We acknowledge the great support of Bijay Raj Subedi, Madan K. Suwal, Yadu Sapkota and Chandra Kanta Subedi in logistics and administrative issues. We are indebted to Nepalese authorities for research permits and to the community in Rolwaling for friendly cooperation and hospitality. We thank the editor and anonymous reviewers for their constructive comments.

Conflicts of Interest: The authors declare no conflict of interest.

\section{Appendix}
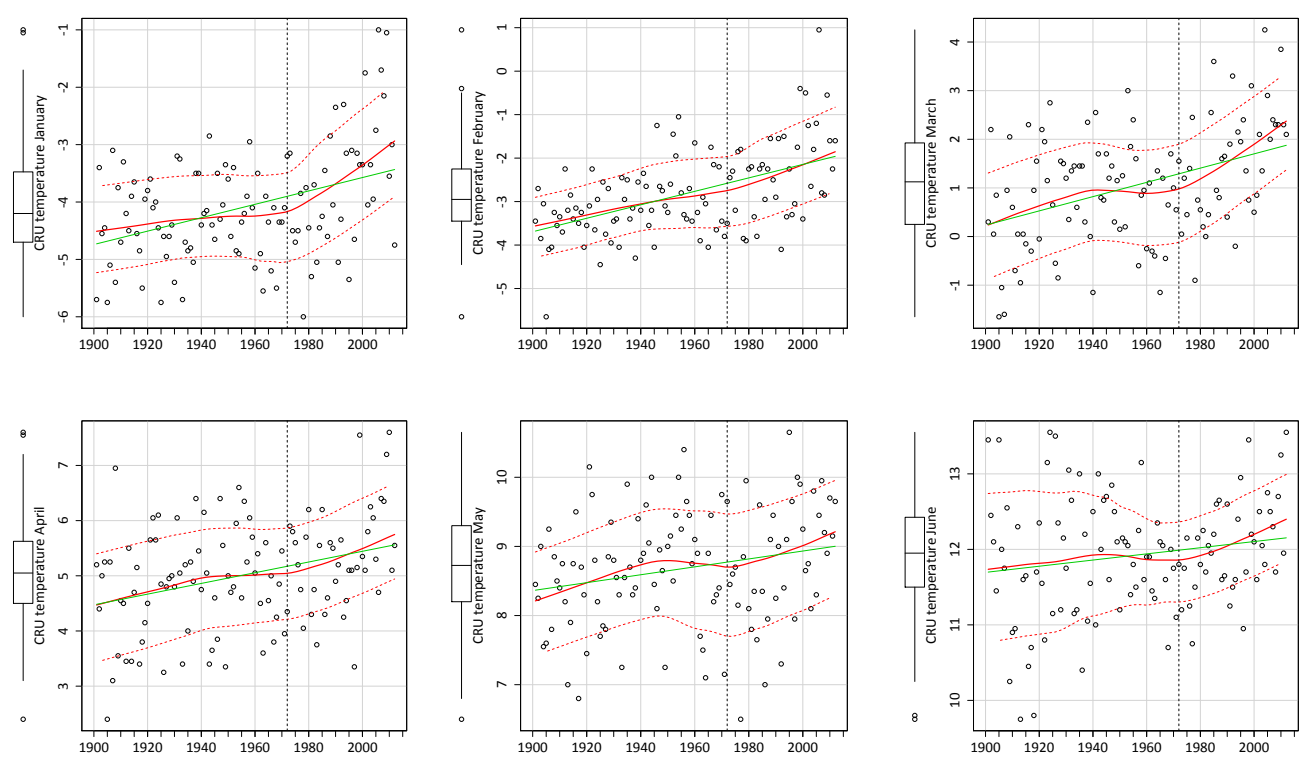

Figure A1. Cont. 

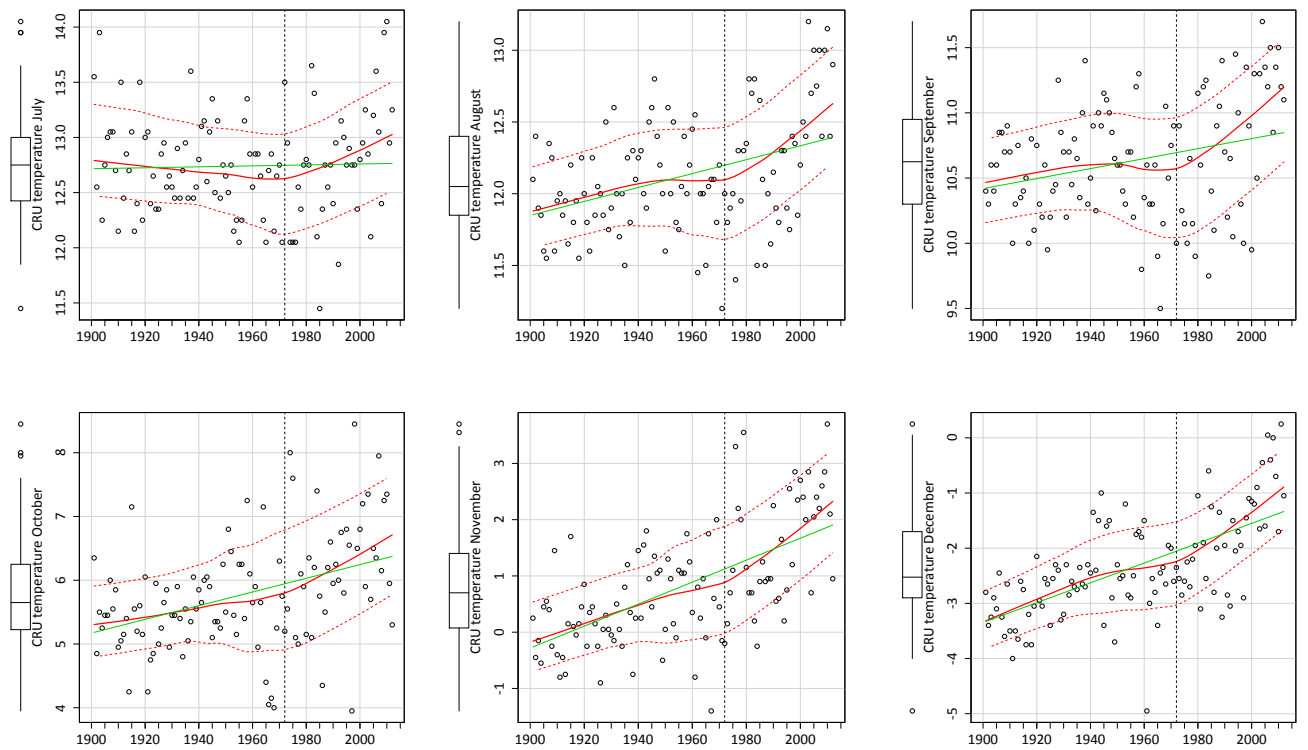

Figure A1. Monthly CRU TS 4.0 temperature non-parametric trends 1901-2012 of the study area. The solid and dashed red lines show locally weighted scatterplot smoothing (LOESS) and corresponding spread smooths, respectively. For comparison, the green line illustrates a linear regression. The dashed black line indicates 1972, i.e., the first year of the period that was analyzed by static tree growth-climate correlations.
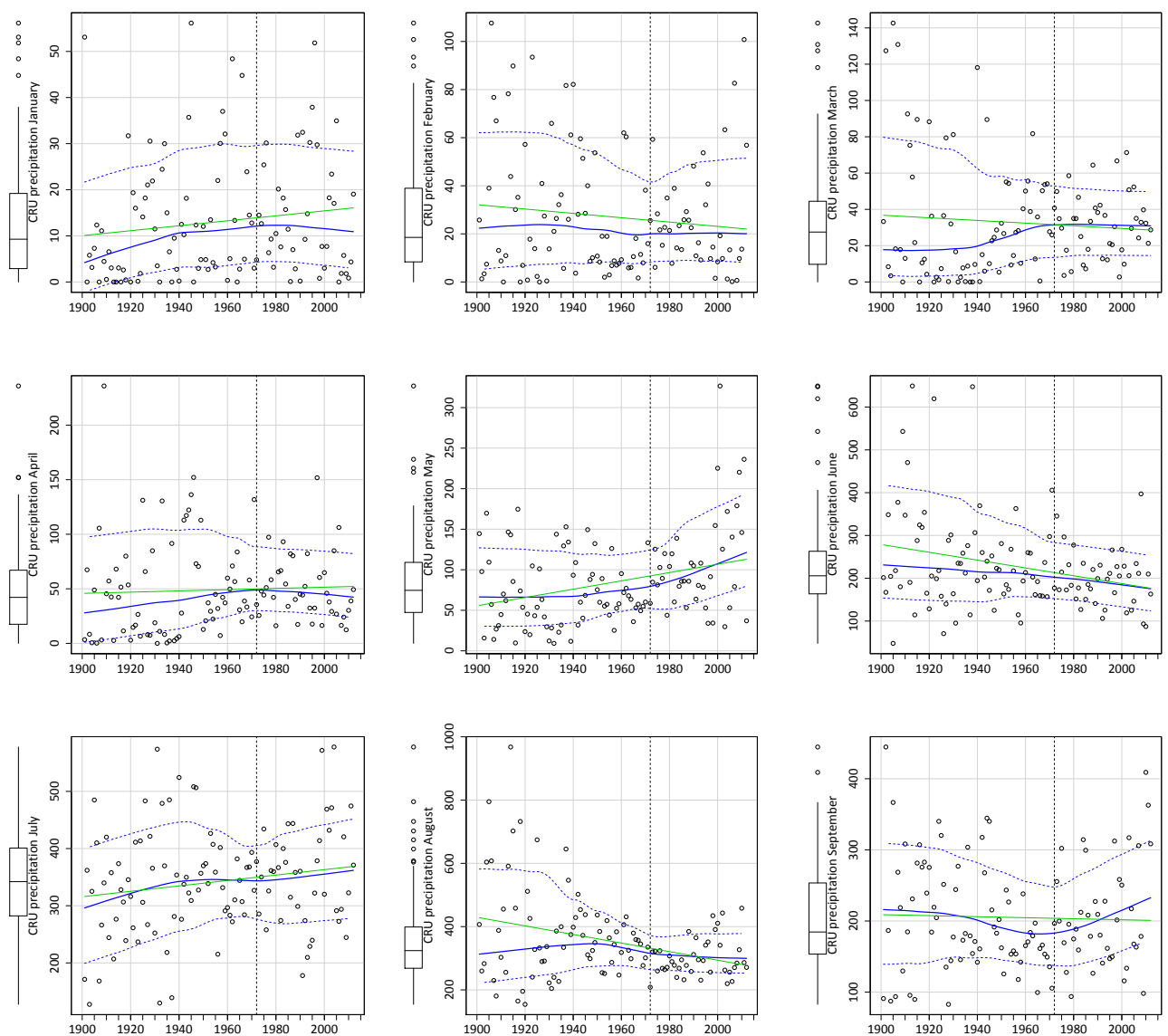

Figure A2. Cont. 



Figure A2. Monthly CRU TS 4.0 precipitation non-parametric trends 1901-2012 of the study area. The solid and dashed red lines show locally weighted scatterplot smoothing (LOESS) and. corresponding spread smooths, respectively. For comparison, the green line illustrates a linear regression. The dashed black line indicates 1972, i.e., the first year of the period that was analyzed by static tree growth-climate correlations.
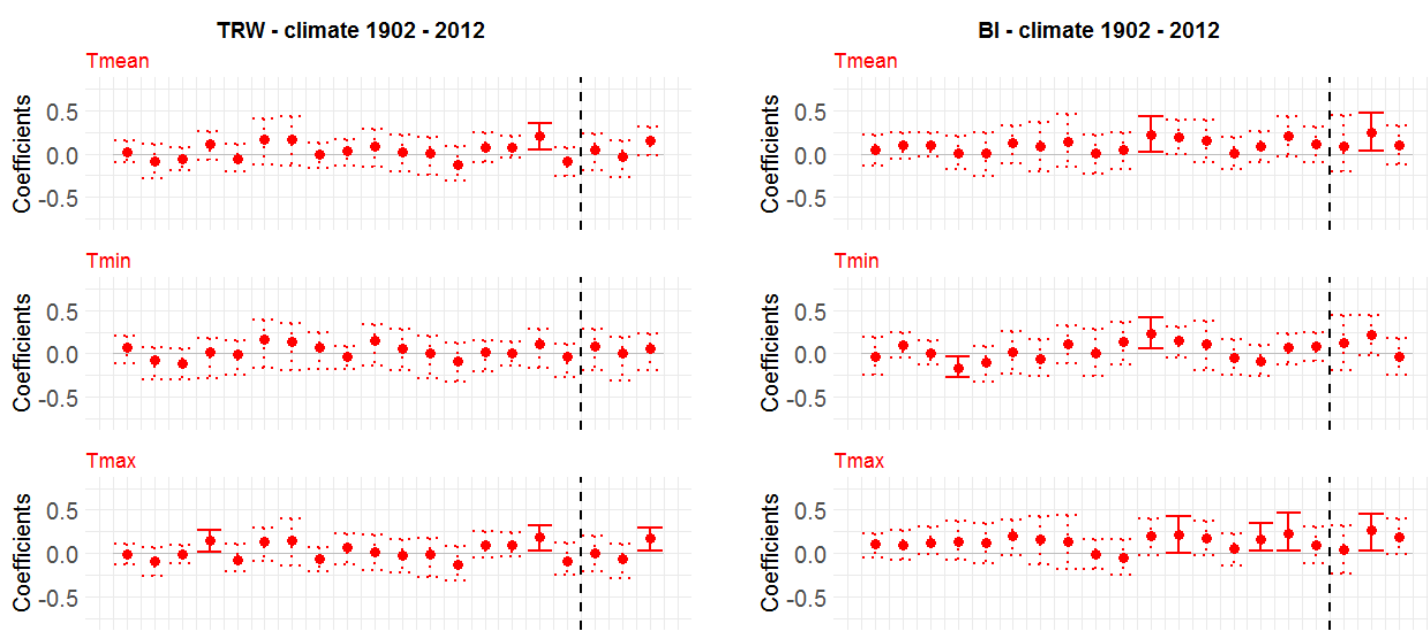

Precipitation
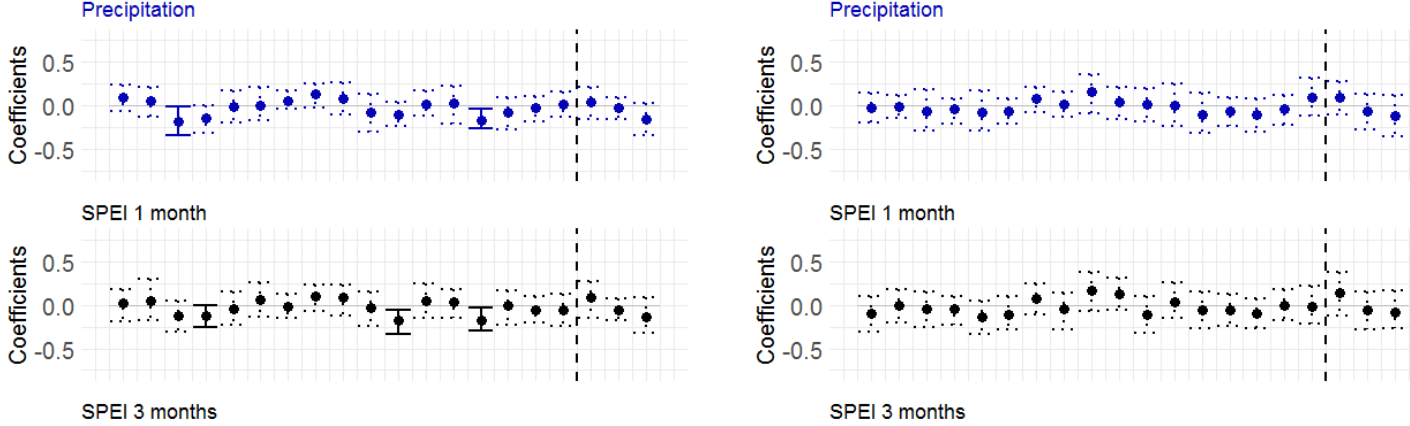

EI 3 months

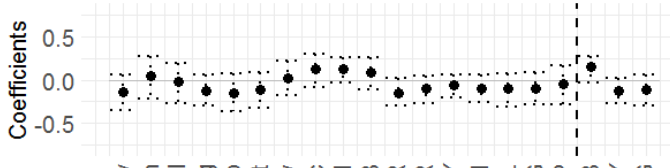

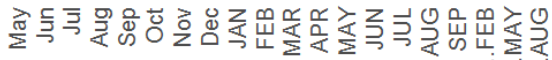

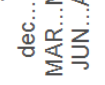

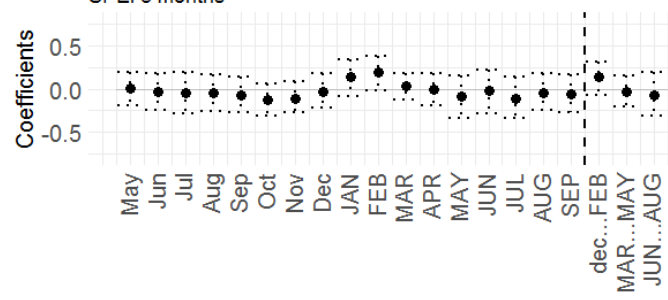

Figure A3. The 1902-2012 static correlations of tree-ring width (TRW, left) and Blue Intensity (BI, right) with temperature, precipitation and drought indices for current and previous year's months and current year seasons. Three-month SPEI correlations were calculated for the period 1903-2012. Solid bars indicate significant correlations $(p<0.05)$. 


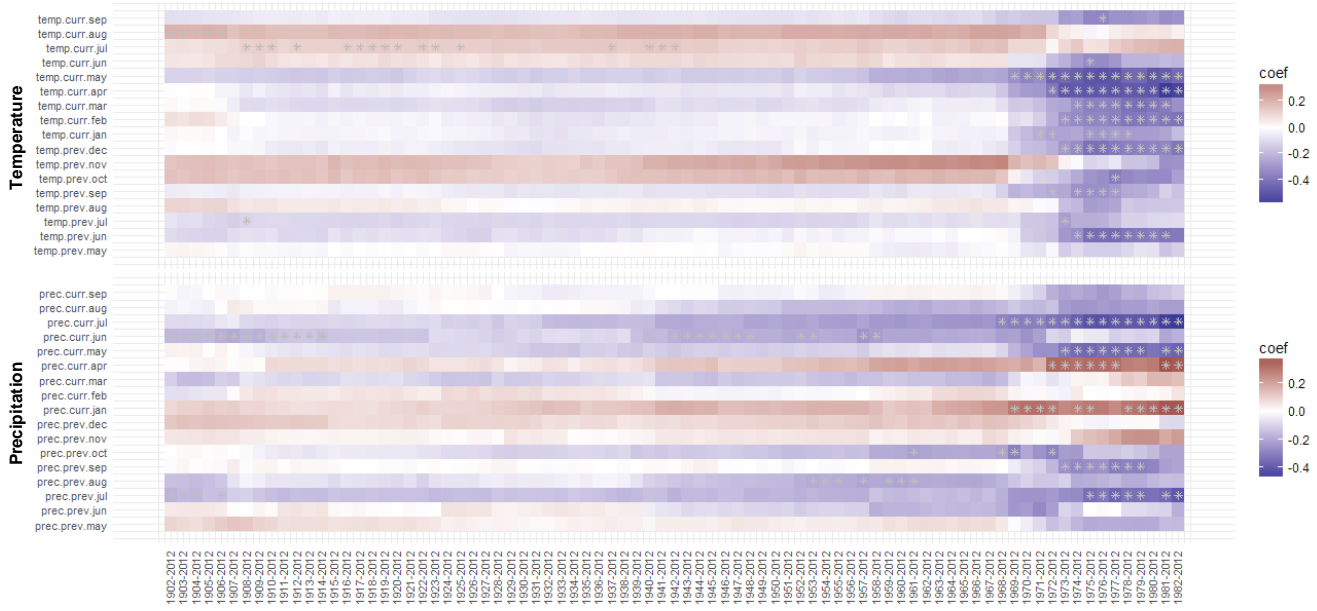

Figure A4. TRW-mean temperatures and TRW-precipitation sums evolving window correlations. Periods with asterisk indicate significant $(p<0.05)$ correlations.

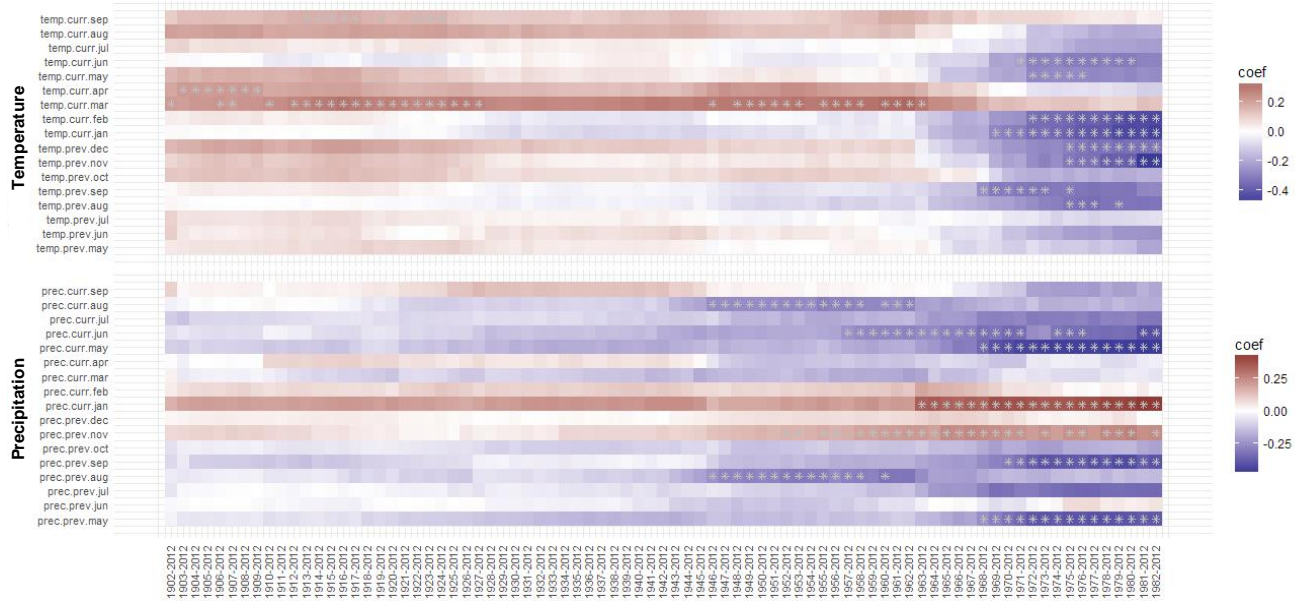

Figure A5. BI-mean temperatures and BI-precipitation sums evolving window correlations. Periods with asterisk indicate significant $(p<0.05)$ correlations.

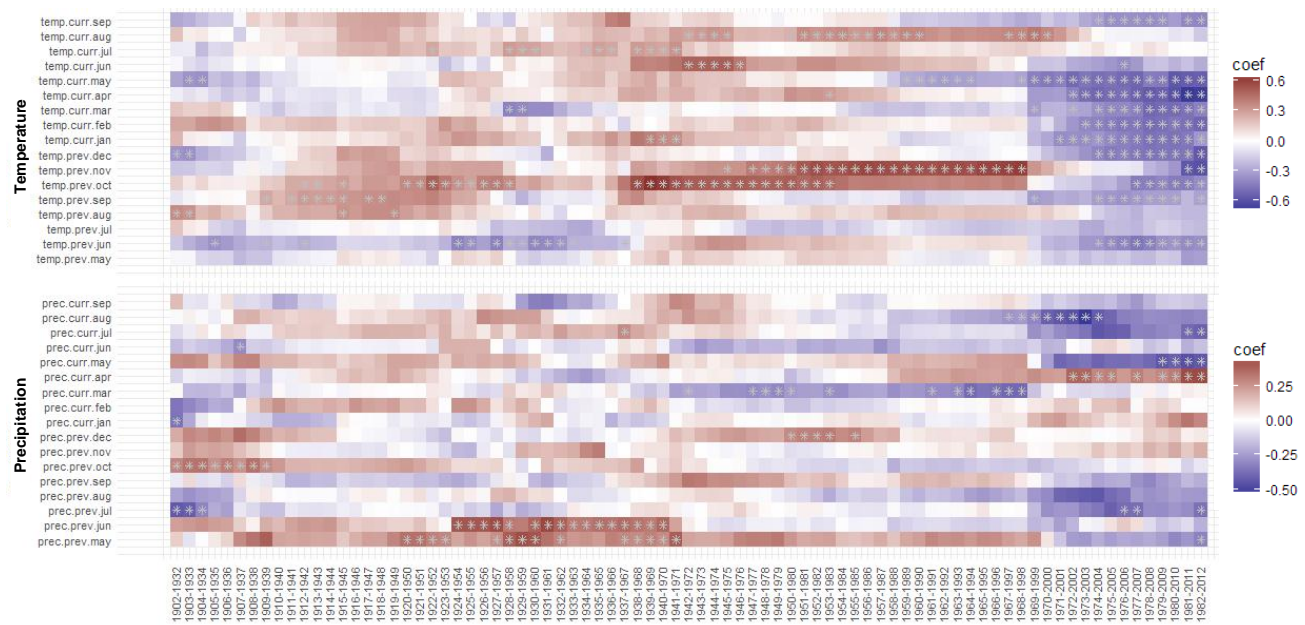

Figure A6. Non-detrended TRW-mean temperatures and non-detrended TRW-precipitation sums moving window correlations. Periods with asterisk indicate significant $(p<0.05)$ correlations. 




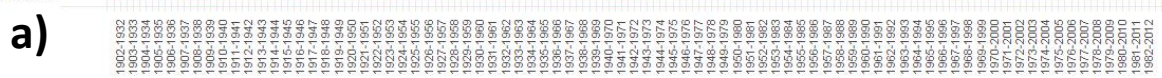

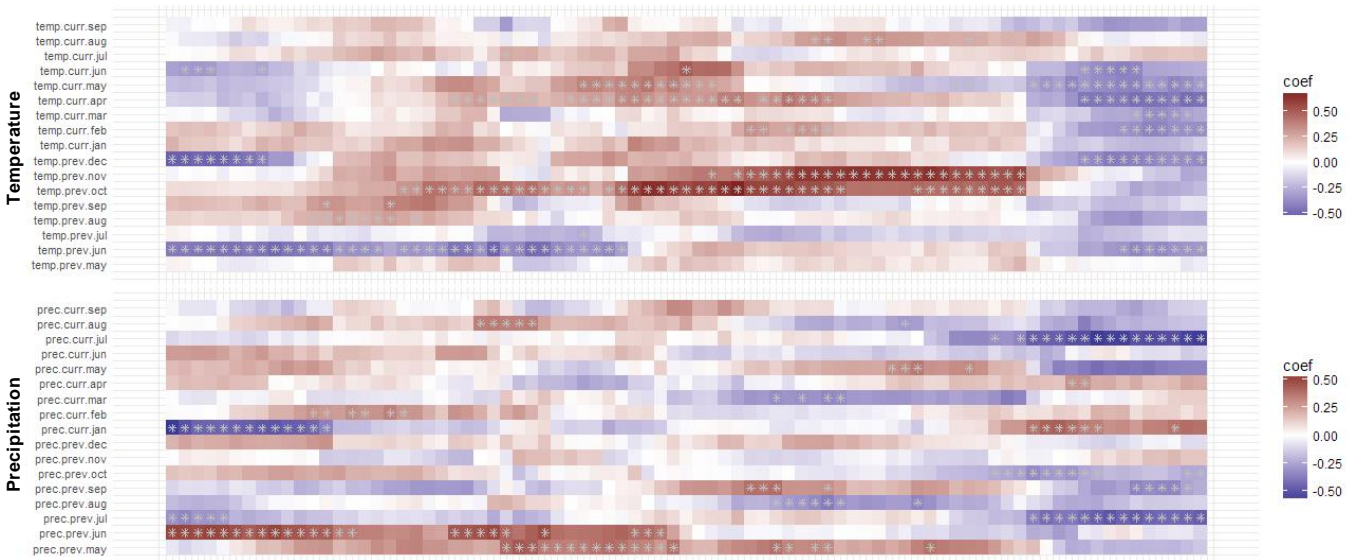



Figure A7. Older trees with minimum age of 100 years (a) show unstable radial growth-climate interactions similar to younger trees with an age of less than 100 years $(\mathbf{b})$.

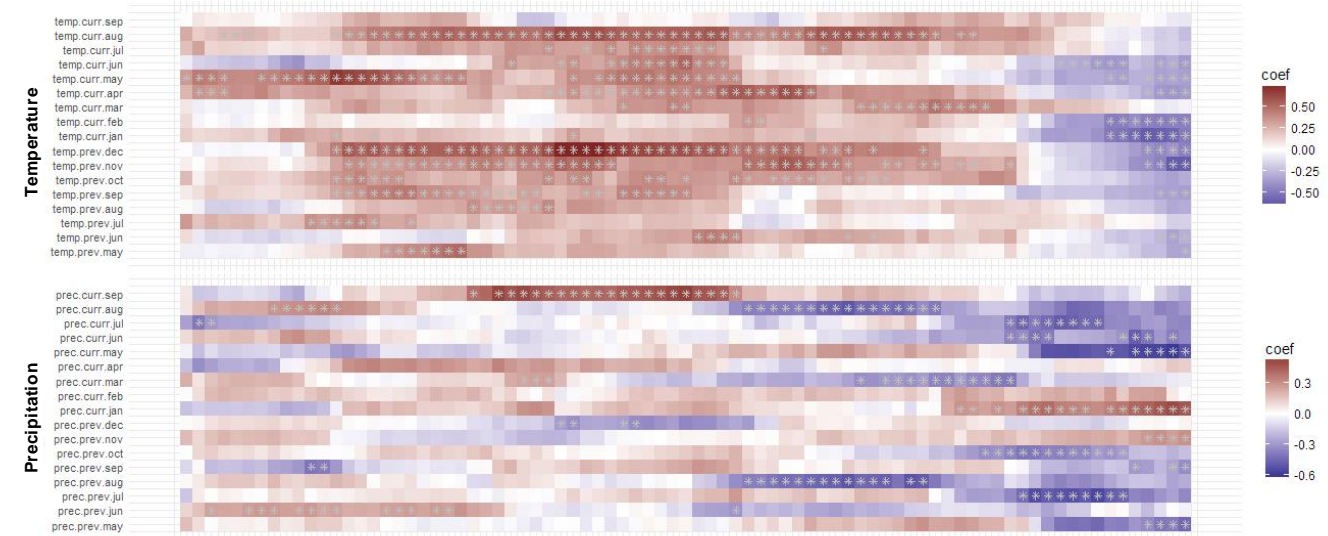

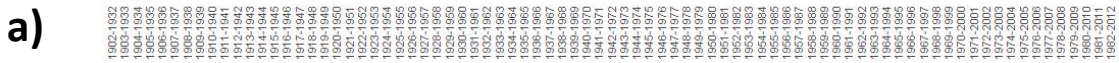

Figure A8. Cont. 


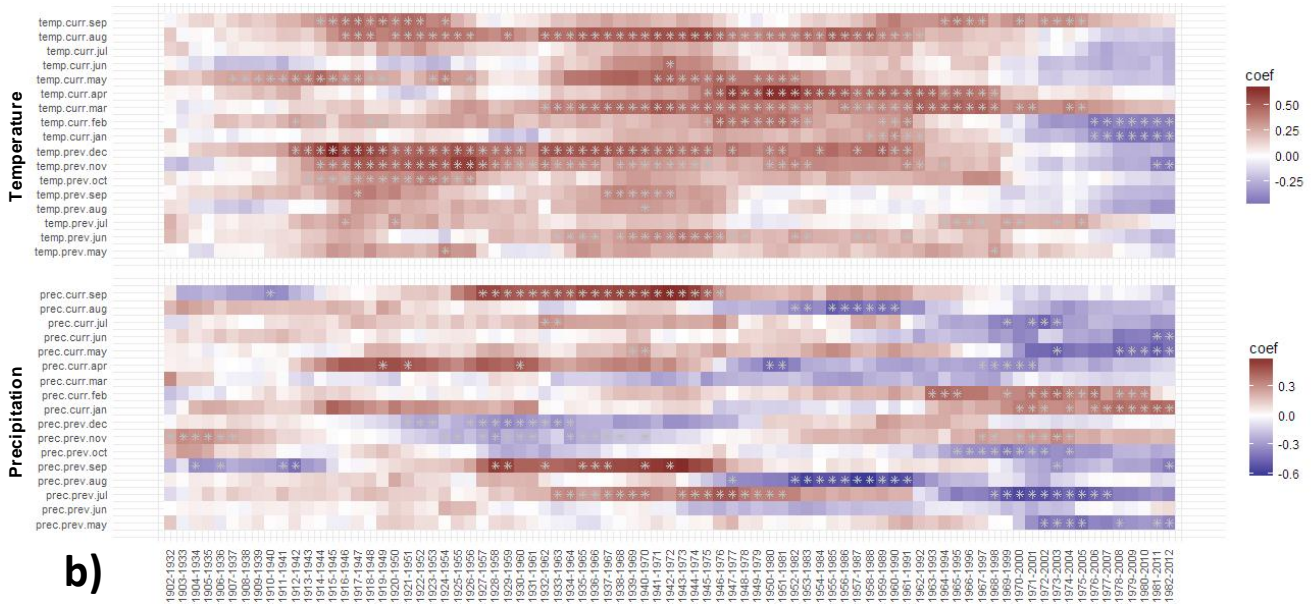

Figure A8. Older trees with minimum age of 100 years (a) show unstable Blue Intensity-climate interactions similar to younger trees with an age of less than 100 years $(\mathbf{b})$.

\section{References}

1. IPCC Climate Change 2014: Impacts, Adaptation, and Vulnerability. Part A: Global and Sectoral Aspects; Contribution of Working Group II to the Fifth Assessment Report of the Intergovernmental Panel on Climate Change; Cambridge University Press: Cambridge, UK; New York, NY, USA, 2014; ISBN 978-1-107-64165-5.

2. Mountain Research Initiative EDW Working Group. Elevation-dependent warming in mountain regions of the world. Nat. Clim. Chang. 2015, 5, 424-430. [CrossRef]

3. Schickhoff, U.; Singh, R.B.; Mal, S. Climate change and dynamics of glaciers and vegetation in the Himalaya: An overview. In Climate Change, Glacier Response, and Vegetation Dynamics in the Himalaya; Singh, R.B., Schickhoff, U., Mal, S., Eds.; Springer International Publishing: Cham, Switzerland, 2016; pp. 1-26, ISBN 978-3-319-28975-5.

4. Shrestha, U.B.; Gautam, S.; Bawa, K.S. Widespread climate change in the Himalayas and associated changes in local ecosystems. PLoS ONE 2012, 7, e36741. [CrossRef] [PubMed]

5. Telwala, Y.; Brook, B.W.; Manish, K.; Pandit, M.K. Climate-induced elevational range shifts and increase in plant species richness in a Himalayan biodiversity epicentre. PLoS ONE 2013, 8, e57103. [CrossRef] [PubMed]

6. Zhang, Y.; Gao, J.; Liu, L.; Wang, Z.; Ding, M.; Yang, X. NDVI-based vegetation changes and their responses to climate change from 1982 to 2011: A case study in the Koshi River Basin in the middle Himalayas. Glob. Planet. Chang. 2013, 108, 139-148. [CrossRef]

7. Salick, J.; Ghimire, S.K.; Fang, Z.; Dema, S.; Konchar, K.M. Himalayan alpine vegetation, climate change and mitigation. J. Ethnobiol. 2014, 34, 276-293. [CrossRef]

8. Dawadi, B.; Liang, E.; Tian, L.; Devkota, L.P.; Yao, T. Pre-monsoon precipitation signal in tree rings of timberline Betula utilis in the central Himalayas. Quat. Int. 2013, 283, 72-77. [CrossRef]

9. Liang, E.; Dawadi, B.; Pederson, N.; Eckstein, D. Is the growth of birch at the upper timberline in the Himalayas limited by moisture or by temperature? Ecology 2014, 95, 2453-2465. [CrossRef]

10. Gaire, N.P.; Koirala, M.; Bhuju, D.R.; Carrer, M. Site- and species-specific treeline responses to climatic variability in eastern Nepal Himalaya. Dendrochronologia 2017, 41, 44-56. [CrossRef]

11. Kharal, D.K.; Thapa, U.K.; St. George, S.; Meilby, H.; Rayamajhi, S.; Bhuju, D.R. Tree-climate relations along an elevational transect in Manang Valley, central Nepal. Dendrochronologia 2017, 41, 57-64. [CrossRef]

12. Tiwari, A.; Fan, Z.-X.; Jump, A.S.; Li, S.-F.; Zhou, Z.-K. Gradual expansion of moisture sensitive Abies spectabilis forest in the Trans-Himalayan zone of central Nepal associated with climate change. Dendrochronologia 2017, 41, 34-43. [CrossRef]

13. Harsch, M.A.; Hulme, P.E.; McGlone, M.S.; Duncan, R.P. Are treelines advancing? A global meta-analysis of treeline response to climate warming. Ecol. Lett. 2009, 12, 1040-1049. [CrossRef] [PubMed] 
14. Malanson, G.P.; Resler, L.M.; Bader, M.Y.; Holtmeier, F.-K.; Butler, D.R.; Weiss, D.J.; Daniels, L.D.; Fagre, D.B. Mountain treelines: A roadmap for research orientation. Arct. Antarct. Alp. Res. 2011, 43, 167-177. [CrossRef]

15. Wieser, G.; Holtmeier, F.-K.; Smith, W.K. Treelines in a changing global environment. In Trees in a Changing Environment; Tausz, M., Grulke, N., Eds.; Springer: Dordrecht, The Netherlands, 2014; pp. 221-263, ISBN 978-94-017-9099-4.

16. Way, D.A.; Oren, R. Differential responses to changes in growth temperature between trees from different functional groups and biomes: A review and synthesis of data. Tree Physiol. 2010, 30, 669-688. [CrossRef] [PubMed]

17. Körner, C. Alpine Treelines: Functional Ecology of the Global High Elevation Tree Limits; Springer: Basel, Switzerland, 2012; ISBN 3-0348-0395-8.

18. Müller, M.; Schickhoff, U.; Scholten, T.; Drollinger, S.; Böhner, J.; Chaudhary, R.P. How do soil properties affect alpine treelines? General principles in a global perspective and novel findings from Rolwaling Himal, Nepal. Prog. Phys. Geogr. 2016, 40, 135-160. [CrossRef]

19. Vaganov, E.A.; Hughes, M.K.; Kirdyanov, A.V.; Schweingruber, F.H.; Silkin, P.P. Influence of snowfall and melt timing on tree growth in subarctic Eurasia. Nature 1999, 400, 149-151. [CrossRef]

20. Gaire, N.P.; Bhuju, D.R.; Koirala, M. Dendrochronological studies in Nepal: Current status and future prospects. FUUAST J. Biol. 2013, 3, 1-9.

21. Schickhoff, U.; Bobrowski, M.; Böhner, J.; Bürzle, B.; Chaudhary, R.P.; Gerlitz, L.; Heyken, H.; Lange, J.; Müller, M.; Scholten, T.; et al. Do Himalayan treelines respond to recent climate change? An evaluation of sensitivity indicators. Earth Syst. Dyn. 2015, 6, 245-265. [CrossRef]

22. Schwab, N.; Schickhoff, U.; Bürzle, B.; Hellmold, J.; Stellmach, M. Dendroecological studies in the Nepal Himalaya-Review and outlook in the context of a new research initiative (TREELINE). In TRACE-Tree Rings in Archaeology, Climatology and Ecology; Wilson, R., Helle, G., Gaertner, H., Eds.; Scientific Technical Report; GFZ German Research Centre for Geosciences: Potsdam, Germany, 2015; Volume 13, pp. 86-95.

23. Chaudhary, V.; Bhattacharyya, A.; Yadav, R.R. Tree-ring studies in the eastern Himalayan region: Prospects and problems. IAWA J. 1999, 20, 317-324. [CrossRef]

24. Cook, E.R.; Krusic, P.J.; Jones, P.D. Dendroclimatic signals in long tree-ring chronologies from the Himalayas of Nepal. Int. J. Climatol. 2003, 23, 707-732. [CrossRef]

25. Ahmed, M.; Palmer, J.; Khan, N.; Wahab, M.; Fenwick, P.; Esper, J.; Cook, E. The dendroclimatic potential of conifers from northern Pakistan. Dendrochronologia 2011, 29, 77-88. [CrossRef]

26. Yadav, R.R.; Bräuning, A.; Singh, J. Tree ring inferred summer temperature variations over the last millennium in western Himalaya, India. Clim. Dyn. 2011, 36, 1545-1554. [CrossRef]

27. Thapa, U.K.; George, S.S.; Kharal, D.K.; Gaire, N.P. Tree growth across the Nepal Himalaya during the last four centuries. Prog. Phys. Geogr. 2017, 41, 478-495. [CrossRef]

28. Shrestha, K.B.; Hofgaard, A.; Vandvik, V. Tree-growth response to climatic variability in two climatically contrasting treeline ecotone areas, central Himalaya, Nepal. Can. J. For. Res. 2015, 45, 1643-1653. [CrossRef]

29. Shrestha, K.B.; Chhetri, P.K.; Bista, R. Growth responses of Abies spectabilis to climate variations along an elevational gradient in Langtang National Park in the central Himalaya, Nepal. J. For. Res. 2017, 22, 274-281. [CrossRef]

30. Chhetri, P.K.; Cairns, D.M. Dendroclimatic response of Abies spectabilis at treeline ecotone of Barun Valley, eastern Nepal Himalaya. J. For. Res. 2016, 27, 1163-1170. [CrossRef]

31. Rayback, S.A.; Shrestha, K.B.; Hofgaard, A. Growth variable-specific moisture and temperature limitations in co-occurring alpine tree and shrub species, central Himalayas, Nepal. Dendrochronologia 2017, 44, 193-202. [CrossRef]

32. Gaire, N.P.; Dhakal, Y.R.; Lekhak, H.C.; Bhuju, D.R.; Shah, S.K. Dynamics of Abies spectabilis in relation to climate change at the treeline ecotone in Langtang National Park. Nepal J. Sci. Technol. 2011, 12, 220-229. [CrossRef]

33. Gaire, N.P.; Bhuju, D.R.; Koirala, M.; Shah, S.K.; Carrer, M.; Timilsena, R. Tree-ring based spring precipitation reconstruction in western Nepal Himalaya since AD 1840. Dendrochronologia 2017, 42, 21-30. [CrossRef]

34. Fritts, H.C. Tree Rings and Climate; Academic Press: London, UK; New York, NY, USA, 1976; ISBN 0-12-268450-8.

35. Nash, T.H.; Kincaid, W.B. Statistical methods for detecting environmental changes. In Methods of Dendrochronology: Applications in the Environmental Science; Cook, E., Kairiukstis, L., Eds.; Kluwer Academic Publishers: Dordrecht, The Netherlands, 1990; pp. 232-239, ISBN 0-7923-0586-8. 
36. Speer, J.H. Fundamentals of Tree-Ring Research; University of Arizona Press: Tucson, AZ, USA, 2010; ISBN 978-0-8165-2684-0.

37. Mitscherlich, E.A. Das Gesetz des Minimums und das Gesetz des abnehmenden Bodenertrages. Landwirtsch. Jahrb. 1909, 38, 537-552.

38. Ohse, B.; Jansen, F.; Wilmking, M. Do limiting factors at Alaskan treelines shift with climatic regimes? Environ. Res. Lett. 2012, 7, 015505. [CrossRef]

39. Wilmking, M.; Scharnweber, T.; van der Maaten-Theunissen, M.; van der Maaten, E. Reconciling the community with a concept-The uniformitarian principle in the dendro-sciences. Dendrochronologia 2017, 44, 211-214. [CrossRef]

40. Jacoby, G.C.; D'Arrigo, R.D. Tree ring width and density evidence of climatic and potential forest change in Alaska. Glob. Biogeochem. Cycles 1995, 9, 227-234. [CrossRef]

41. Briffa, K.R.; Schweingruber, F.H.; Jones, P.D.; Osborn, T.J.; Harris, I.C.; Shiyatov, S.G.; Vaganov, E.A.; Grudd, H. Trees tell of past climates: But are they speaking less clearly today? Philos. Trans. R. Soc. Lond. B Biol. Sci. 1998, 353, 65-73. [CrossRef]

42. Carrer, M.; Urbinati, C. Long-term change in the sensitivity of tree-ring growth to climate forcing in Larix decidua. New Phytol. 2006, 170, 861-872. [CrossRef] [PubMed]

43. D'Arrigo, R.; Wilson, R.; Liepert, B.; Cherubini, P. On the 'divergence problem' in northern forests: A review of the tree-ring evidence and possible causes. Glob. Planet. Chang. 2008, 60, 289-305. [CrossRef]

44. Pellizzari, E.; Camarero, J.J.; Gazol, A.; Granda, E.; Shetti, R.; Wilmking, M.; Moiseev, P.; Pividori, M.; Carrer, M. Diverging shrub and tree growth from the Polar to the Mediterranean biomes across the European continent. Glob. Chang. Biol. 2017, 23, 3169-3180. [CrossRef] [PubMed]

45. Esper, J.; Frank, D.; Büntgen, U.; Verstege, A.; Hantemirov, R.M.; Kirdyanov, A.V. Trends and uncertainties in Siberian indicators of 20th century warming. Glob. Chang. Biol. 2010, 16, 386-398. [CrossRef]

46. Zhang, Y.; Shao, X.; Wilmking, M. Dynamic relationships between Picea crassifolia growth and climate at upper treeline in the Qilian Mts., Northeast Tibetan Plateau, China. Dendrochronologia 2011, 29, 185-199. [CrossRef]

47. Buras, A.; Spyt, B.; Janecka, K.; Kaczka, R. Divergent growth of Norway spruce on Babia Góra Mountain in the western Carpathians. Dendrochronologia 2018, 50, 33-43. [CrossRef]

48. Zhang, Y.; Wilmking, M. Divergent growth responses and increasing temperature limitation of Qinghai spruce growth along an elevation gradient at the northeast Tibet Plateau. For. Ecol. Manag. 2010, 260, 1076-1082. [CrossRef]

49. D’Arrigo, R.D.; Kaufmann, R.K.; Davi, N.; Jacoby, G.C.; Laskowski, C.; Myneni, R.B.; Cherubini, P. Thresholds for warming-induced growth decline at elevational tree line in the Yukon Territory, Canada. Glob. Biogeochem. Cycles 2004, 18, GB3021. [CrossRef]

50. Cook, E.R.; Esper, J.; D'Arrigo, R.D. Extra-tropical Northern Hemisphere land temperature variability over the past 1000 years. Quat. Sci. Rev. 2004, 23, 2063-2074. [CrossRef]

51. Briffa, K.R.; Schweingruber, F.H.; Jones, P.D.; Osborn, T.J.; Shiyatov, S.G.; Vaganov, E.A. Reduced sensitivity of recent tree-growth to temperature at high northern latitudes. Nature 1998, 391, 678-682. [CrossRef]

52. Schneider, L.; Esper, J.; Timonen, M.; Büntgen, U. Detection and evaluation of an early divergence problem in northern Fennoscandian tree-ring data. Oikos 2014, 123, 559-566. [CrossRef]

53. Galván, J.D.; Büntgen, U.; Ginzler, C.; Grudd, H.; Gutiérrez, E.; Labuhn, I.; Julio Camarero, J. Drought-induced weakening of growth-temperature associations in high-elevation Iberian pines. Glob. Planet. Chang. 2015, 124, 95-106. [CrossRef]

54. Ponocná, T.; Spyt, B.; Kaczka, R.; Büntgen, U.; Treml, V. Growth trends and climate responses of Norway spruce along elevational gradients in east-central Europe. Trees 2016, 30, 1633-1646. [CrossRef]

55. Buras, A.; Schunk, C.; Zeiträg, C.; Herrmann, C.; Kaiser, L.; Lemme, H.; Straub, C.; Taeger, S.; Gößwein, S.; Klemmt, H.-J.; et al. Are Scots pine forest edges particularly prone to drought-induced mortality? Environ. Res. Lett. 2018, 13, 025001. [CrossRef]

56. Carrer, M. Individualistic and time-varying tree-ring growth to climate sensitivity. PLOS ONE 2011, 6, e22813. [CrossRef] [PubMed]

57. Hughes, M.K. Dendroclimatology in high-resolution paleoclimatology. In Dendroclimatology; Hughes, M.K., Swetnam, T.W., Diaz, H.F., Eds.; Springer Netherlands: Dordrecht, The Netherlands, 2011; pp. 17-34, ISBN 978-1-4020-4010-8. 
58. Thapa, U.K.; Shah, S.K.; Gaire, N.P.; Bhuju, D.R. Spring temperatures in the far-western Nepal Himalaya since AD 1640 reconstructed from Picea smithiana tree-ring widths. Clim. Dyn. 2015, 45, 2069-2081. [CrossRef]

59. Sohar, K.; Altman, J.; Lehečková, E.; Doležal, J. Growth-climate relationships of Himalayan conifers along elevational and latitudinal gradients. Int. J. Climatol. 2016, 2593-2605. [CrossRef]

60. Frank, D.; Esper, J. Characterization and climate response patterns of a high-elevation, multi-species tree-ring network in the European Alps. Dendrochronologia 2005, 22, 107-121. [CrossRef]

61. Björklund, J.; Gunnarson, B.E.; Seftigen, K.; Zhang, P.; Linderholm, H.W. Using adjusted Blue Intensity data to attain high-quality summer temperature information: A case study from Central Scandinavia. Holocene 2015, 25, 547-556. [CrossRef]

62. Babst, F.; Bouriaud, O.; Papale, D.; Gielen, B.; Janssens, I.A.; Nikinmaa, E.; Ibrom, A.; Wu, J.; Bernhofer, C.; Köstner, B.; et al. Above-ground woody carbon sequestration measured from tree rings is coherent with net ecosystem productivity at five eddy-covariance sites. New Phytol. 2014, 201, 1289-1303. [CrossRef] [PubMed]

63. Bouriaud, O.; Teodosiu, M.; Kirdyanov, A.V.; Wirth, C. Influence of wood density in tree-ring-based annual productivity assessments and its errors in Norway spruce. Biogeosciences 2015, 12, 6205-6217. [CrossRef]

64. Pompa-García, M.; Venegas-González, A. Temporal variation of wood density and carbon in two elevational sites of Pinus cooperi in relation to climate response in northern Mexico. PLoS ONE 2016, 11, e0156782. [CrossRef] [PubMed]

65. Sano, M.; Furuta, F.; Kobayashi, O.; Sweda, T. Temperature variations since the mid-18th century for western Nepal, as reconstructed from tree-ring width and density of Abies spectabilis. Dendrochronologia 2005, 23, 83-92. [CrossRef]

66. Kaczka, R.J.; Spyt, B.; Janecka, K.; Beil, I.; Büntgen, U.; Scharnweber, T.; Nievergelt, D.; Wilmking, M. Different maximum latewood density and blue intensity measurements techniques reveal similar results. Dendrochronologia 2018, 49, 94-101. [CrossRef]

67. McCarroll, D.; Pettigrew, E.; Luckman, A.; Guibal, F.; Edouard, J.-L. Blue reflectance provides a surrogate for latewood density of high-latitude Pine tree rings. Arct. Antarct. Alp. Res. 2002, 34, 450-453. [CrossRef]

68. Campbell, R.; McCarroll, D.; Loader, N.J.; Grudd, H.; Robertson, I.; Jalkanen, R. Blue intensity in Pinus sylvestris tree-rings: Developing a new palaeoclimate proxy. Holocene 2007, 17, 821-828. [CrossRef]

69. McCarroll, D.; Tuovinen, M.; Campbell, R.; Gagen, M.; Grudd, H.; Jalkanen, R.; Loader, N.J.; Robertson, I. A critical evaluation of multi-proxy dendroclimatology in northern Finland. J. Quat. Sci. 2011, 26, 7-14. [CrossRef]

70. Björklund, J.A.; Gunnarson, B.E.; Seftigen, K.; Esper, J.; Linderholm, H.W. Blue intensity and density from northern Fennoscandian tree rings, exploring the potential to improve summer temperature reconstructions with earlywood information. Clim. Past 2014, 10, 877-885. [CrossRef]

71. Rydval, M.; Larsson, L.-Å.; McGlynn, L.; Gunnarson, B.E.; Loader, N.J.; Young, G.H.F.; Wilson, R. Blue intensity for dendroclimatology: Should we have the blues? Experiments from Scotland. Dendrochronologia 2014, 32, 191-204. [CrossRef]

72. Schwab, N.; Schickhoff, U.; Müller, M.; Gerlitz, L.; Bürzle, B.; Böhner, J.; Chaudhary, R.P.; Scholten, T. Treeline responsiveness to climate warming: Insights from a krummholz treeline in Rolwaling Himal, Nepal. In Climate Change, Glacier Response, and Vegetation Dynamics in the Himalaya; Singh, R.B., Schickhoff, U., Mal, S., Eds.; Springer International Publishing: Cham, Switzerland, 2016; pp. 307-345. ISBN 978-3-319-28975-5.

73. Schwab, N.; Schickhoff, U.; Bürzle, B.; Müller, M.; Böhner, J.; Chaudhary, R.P.; Scholten, T.; Oldeland, J. Implications of tree species-Environment relationships for the responsiveness of Himalayan krummholz treelines to climate change. J. Mt. Sci. 2017, 14, 453-473. [CrossRef]

74. Bürzle, B.; Schickhoff, U.; Schickhoff, U.; Schwab, N.; Oldeland, J.; Müller, M.; Böhner, J.; Chaudhary, R.P.; Scholten, T.; Dickoré, W.B. Phytosociology and ecology of treeline ecotone vegetation in Rolwaling Himal, Nepal. Phytocoenologia 2017, 47, 197-220. [CrossRef]

75. Baumgartner, R. Farewell to Yak and Yeti? The Sherpas of Rolwaling Facing a Globalised World; Vajra Books: Kathmandu, Nepal, 2015; ISBN 978-9937-623-43-8.

76. Karki, R.; Talchabhadel, R.; Aalto, J.; Baidya, S.K. New climatic classification of Nepal. Theor. Appl. Climatol. 2016, 125, 799-808. [CrossRef]

77. Karki, R.; Schickhoff, U.; Scholten, T.; Böhner, J. Rising precipitation extremes across Nepal. Climate 2017, 5, 4. [CrossRef] 
78. Karki, R.; ul Hasson, S.; Gerlitz, L.; Schickhoff, U.; Scholten, T.; Böhner, J. Quantifying the added value of convection-permitting climate simulations in complex terrain: A systematic evaluation of WRF over the Himalayas. Earth Syst. Dyn. 2017, 8, 507-528. [CrossRef]

79. Guijarro, J.A. Climatol: Climate Tools (Series Homogenization and Derived Products). R Package Version 3.0. Available online: https:/ /CRAN.R-project.org/package=climatol (accessed on 10 October 2017).

80. Miehe, G.; Miehe, S.; Böhner, J.; Ghimire, S.K.; Bhattarai, K.; Chaudhary, R.P.; Subedi, M.; Jha, P.K.; Pendry, C. Vegetation ecology. In Nepal: An Introduction to the Natural History, Ecology and Human Environment in the Himalayas; Miehe, G., Pendry, C., Chaudhary, R.P., Eds.; Royal Botanic Garden Edinburgh: Edinburgh, UK, 2015; pp. 385-472, ISBN 978-1-910877-02-9.

81. Stokes, M.A.; Smiley, T.L. An Introduction to Tree-Ring Dating; University of Arizona Press: Tucson, AZ, USA, 1996; ISBN 0-8165-1680-4.

82. Müller, M.; Schwab, N.; Schickhoff, U.; Böhner, J.; Scholten, T. Soil temperature and soil moisture patterns in a Himalayan alpine treeline ecotone. Arct. Antarct. Alp. Res. 2016, 48, 501-521. [CrossRef]

83. Schweingruber, F.H. Wood Structure and Environment; Springer: Berlin, Germany; New York, NY, USA, 2007; ISBN 978-3-540-48299-4.

84. Janecka, K.; Kaczka, R.; Gärtner, H.; Treydte, K. The influence of compression wood on the strength of the climatic signal in tree rings of Norway spruce. In TRACE-Tree Rings in Archaeology, Climatology and Ecology; Hevia, A., Sánchez-Salguero, R., Linares, J.C., Olano, J.M., Camarero, J.J., Gutiérrez, E., Helle, G., Gärtner, H., Eds.; Scientific Technical Report; GFZ German Research Centre for Geosciences: Potsdam, Germany, 2016; Volume 14, pp. 50-59.

85. Larsson, L.-Å. CooRecorder and CDendro Programs of the CooRecorder/CDendro Package Version 8.1. Available online: http:/ / www.cybis.se/forfun/dendro/ (accessed on 1 December 2016).

86. Holmes, R.L. Computer-assisted quality control in tree-ring dating and measurement. Tree-Ring Bull. 1983, 43, 69-78.

87. Cook, E.R. A Time Series Analysis Approach to Tree Ring Standardization; University of Arizona: Tucson, AZ, USA, 1985.

88. Esper, J.; Frank, D. Divergence pitfalls in tree-ring research. Clim. Chang. 2009, 94, 261. [CrossRef]

89. Cook, E.R.; Peters, K. Calculating unbiased tree-ring indices for the study of climatic and environmental change. Holocene 1997, 7, 361-370. [CrossRef]

90. Wigley, T.M.L.; Briffa, K.R.; Jones, P.D. On the average value of correlated time series, with applications in dendroclimatology and hydrometeorology. J. Clim. Appl. Meteorol. 1984, 23, 201-213. [CrossRef]

91. Briffa, K.; Jones, P.D. Basic chronology statistics and assessment. In Methods of Dendrochronology: Applications in the Environmental Science; Cook, E., Kairiukstis, L., Eds.; Kluwer Academic Publishers: Dordrecht, The Netherlands, 1990; pp. 137-152. ISBN 0-7923-0586-8.

92. Cook, E.; Briffa, K.; Shiyatov, S.; Mazepa, V. Tree-ring standardization and growth-trend estimation. In Methods of Dendrochronology: Applications in the Environmental Science; Cook, E., Kairiukstis, L., Eds.; Kluwer Academic Publishers: Dordrecht, The Netherlands, 1990; pp. 104-123. ISBN 0-7923-0586-8.

93. Buras, A. A comment on the expressed population signal. Dendrochronologia 2017, 44, 130-132. [CrossRef]

94. Harris, I.; Jones, P.D.; Osborn, T.J.; Lister, D.H. Updated high-resolution grids of monthly climatic observations-The CRU TS3.10 Dataset. Int. J. Climatol. 2014, 34, 623-642. [CrossRef]

95. University of East Anglia Climatic Research Unit; Harris, I.C.; Jones „, P.D. CRU TS4.00: Climatic Research Unit (CRU) Time-Series (TS) Version 4.00 of High Resolution Gridded Data of Month-By-Month Variation in Climate (Jan. 1901-Dec. 2015); Centre for Environmental Data Analysis (CEDA): Didcot, UK, 2017. Available online: http:/ / catalogue.ceda.ac.uk/uuid/edf8febfdaad48abb2cbaf7d7e846a86 (accessed on 17 September 2017).

96. Vicente-Serrano, S.M.; Beguería, S.; López-Moreno, J.I.; Angulo, M.; El Kenawy, A. A new global $0.5^{\circ}$ gridded dataset (1901-2006) of a multiscalar drought index: Comparison with current drought index datasets based on the Palmer Drought Severity Index. J. Hydrometeorol. 2010, 11, 1033-1043. [CrossRef]

97. CRU TS Version 4.01 Google Earth Interface. Available online: https://crudata.uea.ac.uk/cru/data/hrg/ cru_ts_4.01/ge/ (accessed on 16 October 2017).

98. Trouet, V.; Van Oldenborgh, G.J. KNMI Climate Explorer: A web-based research tool for high-resolution paleoclimatology. Tree-Ring Res. 2013, 69, 3-13. [CrossRef]

99. Fox, J.; Weisberg, S. An R Companion to Applied Regression; Sage: Thousand Oaks, CA, USA, 2011; ISBN 978-1-4129-7514-8. 
100. R Core Team. R: A Language and Environment for Statistical Computing; R Foundation for Statistical Computing: Vienna, Austria, 2017.

101. Politis, D.N.; Romano, J.P. The stationary bootstrap. J. Am. Stat. Assoc. 1994, 89, 1303-1313. [CrossRef]

102. Politis, D.N.; White, H. Automatic block-length selection for the dependent bootstrap. Econom. Rev. 2004, 23, 53-70. [CrossRef]

103. Biondi, F.; Waikul, K. DENDROCLIM2002: A C++ program for statistical calibration of climate signals in tree-ring chronologies. Comput. Geosci. 2004, 30, 303-311. [CrossRef]

104. Zang, C.; Biondi, F. treeclim: An R package for the numerical calibration of proxy-climate relationships. Ecography 2015, 38, 431-436. [CrossRef]

105. Fan, Z.-X.; Bräuning, A.; Cao, K.-F. Tree-ring based drought reconstruction in the central Hengduan Mountains region (China) since A.D. 1655. Int. J. Climatol. 2008, 28, 1879-1887. [CrossRef]

106. St. George, S. An overview of tree-ring width records across the Northern Hemisphere. Quat. Sci. Rev. 2014, 95, 132-150. [CrossRef]

107. Wang, S.-Y.; Yoon, J.-H.; Gillies, R.R.; Cho, C. What caused the winter drought in western Nepal during recent years? J. Clim. 2013, 26, 8241-8256. [CrossRef]

108. Dahal, P.; Shrestha, N.S.; Shrestha, M.L.; Krakauer, N.Y.; Panthi, J.; Pradhanang, S.M.; Jha, A.; Lakhankar, T. Drought risk assessment in central Nepal: Temporal and spatial analysis. Nat. Hazards 2015, 1-20. [CrossRef]

109. Naidu, C.V.; Krishna, K.M.; Rao, S.R.; Bhanu Kumar, O.S.R.U.; Durgalakshmi, K.; Ramakrishna, S.S.V.S. Variations of Indian summer monsoon rainfall induce the weakening of easterly jet stream in the warming environment? Glob. Planet. Chang. 2011, 75, 21-30. [CrossRef]

110. Lv, L.-X.; Zhang, Q.-B. Asynchronous recruitment history of Abies spectabilis along an altitudinal gradient in the Mt. Everest region. J. Plant Ecol. 2012, 5, 147-156. [CrossRef]

111. Kharal, D.K.; Meilby, H.; Rayamajhi, S.; Bhuju, D.; Thapa, U.K. Tree ring variability and climate response of Abies spectabilis along an elevation gradient in Mustang, Nepal. Banko Janakari 2014, 24, 3-13. [CrossRef]

112. Bräuning, A.; Grießinger, J. Late holocene variations in monsoon intensity in the Tibetan- Himalayan region-Evidence from tree rings. Geol. Soc. India 2006, 68, 485-493.

113. Borgaonkar, H.P.; Sikder, A.B.; Ram, S. High altitude forest sensitivity to the recent warming: A tree-ring analysis of conifers from Western Himalaya, India. Quat. Int. 2011, 236, 158-166. [CrossRef]

114. Li, J.; Shi, J.; Zhang, D.D.; Yang, B.; Fang, K.; Yue, P.H. Moisture increase in response to high-altitude warming evidenced by tree-rings on the southeastern Tibetan Plateau. Clim. Dyn. 2017, 48, 649-660. [CrossRef]

115. Panthi, S.; Bräuning, A.; Zhou, Z.-K.; Fan, Z.-X. Tree rings reveal recent intensified spring drought in the central Himalaya, Nepal. Glob. Planet. Chang. 2017, 157, 26-34. [CrossRef]

116. Ren, P.; Rossi, S.; Gricar, J.; Liang, E.; Cufar, K. Is precipitation a trigger for the onset of xylogenesis in Juniperus przewalskii on the north-eastern Tibetan Plateau? Ann. Bot. 2015, 115, 629-639. [CrossRef] [PubMed]

117. Tiwari, A.; Fan, Z.-X.; Jump, A.S.; Zhou, Z.-K. Warming induced growth decline of Himalayan birch at its lower range edge in a semi-arid region of Trans-Himalaya, central Nepal. Plant Ecol. 2017, 218, 621-633. [CrossRef]

118. Bräuning, A. Tree-ring studies in the Dolpo-Himalya (western Nepal). In TRACE-Tree Rings in Archaeology, Climatology and Ecology; Schriften des Forschungszentrums Jülich, Reihe Umwelt Volume 44; Jansma, E., Bräuning, A., Gärtner, H., Schleser, G., Eds.; GFZ German Research Centre for Geosciences: Potsdam, Germany, 2004; Volume 2, pp. 8-12.

119. Peterson, D.W.; Peterson, D.L.; Ettl, G.J. Growth responses of subalpine fir to climatic variability in the Pacific Northwest. Can. J. For. Res. 2002, 32, 1503-1517. [CrossRef]

120. Borgaonkar, H.P.; Pant, G.B.; Rupa Kumar, K. Dendroclimatic reconstruction of summer precipitation at Srinagar, Kashmir, India, since the late-eighteenth century. Holocene 1994, 4, 299-306. [CrossRef]

121. Vicente-Serrano, S.M.; Beguería, S.; Lorenzo-Lacruz, J.; Camarero, J.J.; López-Moreno, J.I.; Azorin-Molina, C.; Revuelto, J.; Morán-Tejeda, E.; Sanchez-Lorenzo, A.; Vicente-Serrano, S.M.; et al. Performance of drought indices for ecological, agricultural, and hydrological applications. Earth Interact. 2012, 16, 1-27. [CrossRef]

122. Vaganov, E.A.; Anchukaitis, K.J.; Evans, M.N. How well understood are the processes that create dendroclimatic records? A mechanistic model of the climatic control on conifer tree-ring growth dynamics. In Dendroclimatology; Hughes, M.K., Swetnam, T.W., Diaz, H.F., Eds.; Springer Netherlands: Dordrecht, The Netherlands, 2011; pp. 37-75, ISBN 978-1-4020-4010-8. 
123. Gerlitz, L.; Bechtel, B.; Böhner, J.; Bobrowski, M.; Bürzle, B.; Müller, M.; Scholten, T.; Schickhoff, U.; Schwab, N.; Weidinger, J. Analytic comparison of temperature lapse rates and precipitation gradients in a Himalayan treeline environment: Implications for statistical downscaling. In Climate Change, Glacier Response, and Vegetation Dynamics in the Himalaya; Singh, R.B., Schickhoff, U., Mal, S., Eds.; Springer International Publishing: Cham, Switzerland, 2016; pp. 49-64. ISBN 978-3-319-28975-5.

124. Zurick, D.; Pacheco, J. Illustrated Atlas of the Himalaya; University Press of Kentucky: Lexington, KY, USA, 2006; ISBN 978-0-8131-2388-2.

125. Elliott, G.P.; Cowell, C.M. Slope aspect mediates fine-scale tree establishment patterns at upper treeline during wet and dry periods of the 20th century. Arct. Antarct. Alp. Res. 2015, 47, 681-692. [CrossRef]

126. Bobrowski, M.; Schickhoff, U. Why input matters: Selection of climate data sets for modelling the potential distribution of a treeline species in the Himalayan region. Ecol. Model. 2017, 359, 92-102. [CrossRef]

127. Kaczka, R.J.; Spyt, B.; Janecka, K.; Niedźwiedź, T.; Bednarz, Z. Climate reconstruction from tree-rings in the Tatra mountains. In Flood Risk in the Upper Vistula Basin; Springer: Cham, Switzerland, 2016; pp. 209-229. ISBN 978-3-319-41922-0.

128. Ul Hasson, S.; Gerlitz, L.; Schickhoff, U.; Scholten, T.; Böhner, J. Recent climate change over High Asia. In Climate Change, Glacier Response, and Vegetation Dynamics in the Himalaya; Singh, R.B., Schickhoff, U., Mal, S., Eds.; Springer International Publishing: Cham, Switzerland, 2016; pp. 29-48. ISBN 978-3-319-28975-5.

129. Singh, J.; Yadav, R.R.; Wilmking, M. A 694-year tree-ring based rainfall reconstruction from Himachal Pradesh, India. Clim. Dyn. 2009, 33, 1149-1158. [CrossRef]

130. Yadav, R.R.; Misra, K.G.; Kotlia, B.S.; Upreti, N. Premonsoon precipitation variability in Kumaon Himalaya, India over a perspective of $\sim 300$ years. Quat. Int. 2014, 325, 213-219. [CrossRef]

131. Harris, I. Release Notes for CRU TS v4.01. Available online: https://crudata.uea.ac.uk/cru/data/hrg/cru_ ts_4.01/Release_Notes_CRU_TS4.01.txt (accessed on 15 September 2017).

132. Department of Hydrology and Meteorology (DHM). Study of Climate and Climatic Variation over Nepal; Department of Hydrology and Meteorology (DHM): Kathmandu, Nepal, 2015. Available online: http:// www.dhm.gov.np/uploads / climatic/1407411953Climate\%20and\%20Climatic\%20variability.pdf (accessed on 16 October 2017).

133. Natalini, F.; Alejano, R.; Vázquez-Piqué, J.; Pardos, M.; Calama, R.; Büntgen, U. Spatiotemporal variability of stone pine (Pinus pinea L.) growth response to climate across the Iberian Peninsula. Dendrochronologia 2016, 40, 72-84. [CrossRef]

134. Büntgen, U.; Frank, D.C.; Kaczka, R.J.; Verstege, A.; Zwijacz-Kozica, T.; Esper, J. Growth responses to climate in a multi-species tree-ring network in the Western Carpathian Tatra Mountains, Poland and Slovakia. Tree Physiol. 2007, 27, 689-702. [CrossRef] [PubMed]

135. Kirdyanov, A.V.; Treydte, K.S.; Nikolaev, A.; Helle, G.; Schleser, G.H. Climate signals in tree-ring width, density and $\delta 13 C$ from larches in Eastern Siberia (Russia). Chem. Geol. 2008, 252, 31-41. [CrossRef]

136. Krusic, P.J.; Cook, E.R.; Dukpa, D.; Putnam, A.E.; Rupper, S.; Schaefer, J. Six hundred thirty-eight years of summer temperature variability over the Bhutanese Himalaya. Geophys. Res. Lett. 2015, 42, 2015GL063566. [CrossRef]

137. Sitko, R.; Vido, J.; Škvarenina, J.; Pichler, V.; Scheer, Ĺ.; Škvareninová, J.; Nalevanková, P. Effect of various climate databases on the results of dendroclimatic analysis. Earth Syst. Dyn. 2016, 7, 385-395. [CrossRef]

138. Carrer, M.; Urbinati, C. Age-dependent tree-ring growth responses to climate in Larix decidua and Pinus cembra. Ecology 2004, 85, 730-740. [CrossRef]

139. Altman, J.; Fibich, P.; Santruckova, H.; Dolezal, J.; Stepanek, P.; Kopacek, J.; Hunova, I.; Oulehle, F.; Tumajer, J.; Cienciala, E. Environmental factors exert strong control over the climate-growth relationships of Picea abies in Central Europe. Sci. Total Environ. 2017, 609, 506-516. [CrossRef] [PubMed]

140. Wilmking, M.; Juday, G.P.; Barber, V.A.; Zald, H.S.J. Recent climate warming forces contrasting growth responses of white spruce at treeline in Alaska through temperature thresholds. Glob. Chang. Biol. 2004, 10, 1724-1736. [CrossRef]

141. Wilmking, M.; Juday, G.P. Longitudinal variation of radial growth at Alaska's northern treeline-Recent changes and possible scenarios for the 21st century. Glob. Planet. Chang. 2005, 47, 282-300. [CrossRef]

142. Chhetri, P.K.; Thapa, S. Tree ring and climate change in Langtang National Park, central Nepal. Our Nat. 2010, 8, 139-143. [CrossRef] 
143. Rita, A.; Gentilesca, T.; Ripullone, F.; Todaro, L.; Borghetti, M. Differential climate-growth relationships in Abies alba Mill. and Fagus sylvatica L. in Mediterranean mountain forests. Dendrochronologia 2014, 32, $220-229$. [CrossRef]

144. Jiao, L.; Jiang, Y.; Zhang, W.-T.; Wang, M.-C.; Zhang, L.-N.; Zhao, S.-D. Divergent responses to climate factors in the radial growth of Larix sibirica in the eastern Tianshan Mountains, northwest China. Trees 2015, 29, 1673-1686. [CrossRef]

145. Martin-Benito, D.; Anchukaitis, K.J.; Evans, M.N.; del Río, M.; Beeckman, H.; Cañellas, I. Effects of drought on xylem anatomy and water-use efficiency of two co-occurring Pine species. Forests 2017, 8, 332. [CrossRef]

(C) 2018 by the authors. Licensee MDPI, Basel, Switzerland. This article is an open access article distributed under the terms and conditions of the Creative Commons Attribution (CC BY) license (http://creativecommons.org/licenses/by/4.0/). 